\title{
EVALUATION OF AGROCHEMICAL INTERACTIONS AND APPLICATION TIMINGS IN CORN AND SOYBEAN
}

\author{
A Thesis \\ presented to the Faculty of Graduate School \\ University of Missouri
}

In Partial Fulfillment

Of the Requirements for the Degree

Master of Science

By

CRAIG BRADLEY SOLOMON

Dr. Kevin W. Bradley, Thesis supervisor

December 2013 
The undersigned, appointed by the Dean of the Graduate School, have examined the Thesis entitled:

\section{EVALUATION OF AGROCHEMICAL INTERACTIONS AND APPLICATION TIMINGS IN CORN AND SOYBEAN}

Presented by Craig Bradley Solomon

A candidate for the degree of Master of Science

And hereby certify that in their opinion it is worthy of acceptance.

Dr. Kevin W. Bradley

Associate Professor

Dr. Laura Sweets

Extension Associate Professor

Dr. Christian Boessen

Associate Professor 


\section{ACKNOWLEDGMENTS}

I would first like to thank my advisor Dr. Kevin Bradley for taking me on as a graduate student and assisting me in accomplishing this milestone of my academic career. I am honored to have been able to study under such a motivated and respected individual of our community. I would also like to thank Dr. Laura Sweets and Dr. Chris Boessen for your help and guidance throughout this endeavor.

I would like to thank our technicians Jim Wait, Eric Riley, and former technician Travis Legleiter for much needed advice, assistance, and entertainment. Also, a great deal of thanks goes to past and present graduate students Kristen Rosenbaum, Bryan Sather, Brett Craigmyle, Doug Spaunhorst, and John Schultz. Without your help, support, and positive mentalities this degree would not have been near as enjoyable. I look forward to crossing paths with each and every one of

you in whatever future endeavors you may choose. I would also like to thank all of our employed undergraduate students for their assistance and time.

Most importantly I thank my family and friends for motivation, support, and love. Words cannot describe the amount of appreciation I have for everyone that has been there for me the last few years, not just through this degree but from the beginning. Mom, I can honestly say that I could not be more fortunate and proud to have you as my parent. Know that you are the reason for all of my successes. Katie and John, thank you for being there for me and being such inspiring parents to my beautiful niece, Marley. Pete, Lorene, and Shelby, without your continued guidance, care, and confidence this would have never happened. I love you all so much and look forward to spending more time together soon. 


\section{TABLE OF CONTENTS}

Acknowledgements ii

List of tables .. V

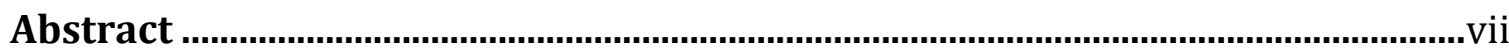

\section{Chapter}

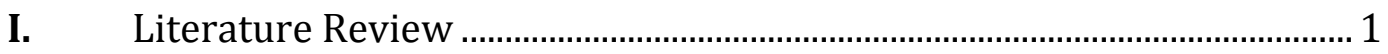

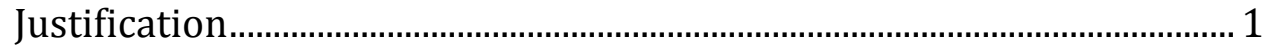

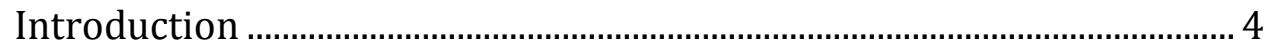

Synthetic Auxin Herbicides.................................................................. 4

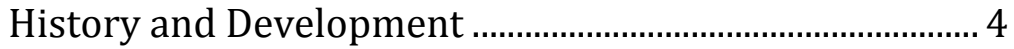

Volatility and Spray Drift Concerns .......................................

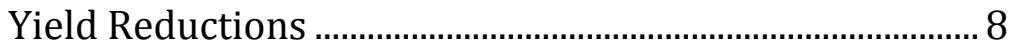

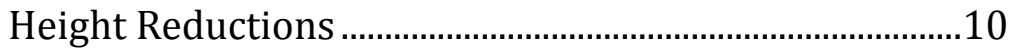

Delayed Maturity …………………………………………....10

Visual Symptomology …………………………………....11

Herbicide-Resistance and New Crop Developments .....12

Herbicide-Agrochemical Co-Applications in Corn ........................16

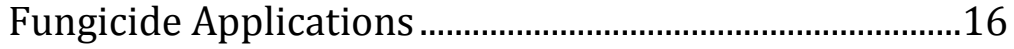

Foliar Fertilization ............................................................20

Summary and Objectives...........................................................................22

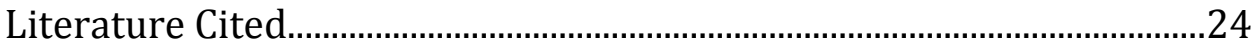

II. Influence of Application Timings and Sub-Lethal Rates of Synthetic

Auxin Herbicides on Soybean............................................................................33

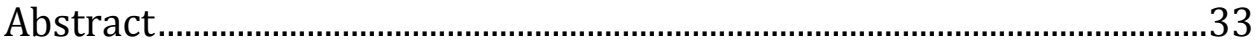

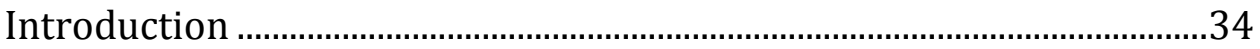

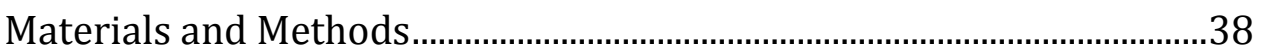

General Trial Information................................................................38

Treatment Evaluation and Data Collection....................................39

Statistical Analysis................................................................................. 40

Results and Discussion................................................................................4

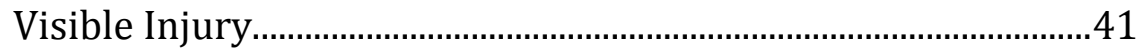

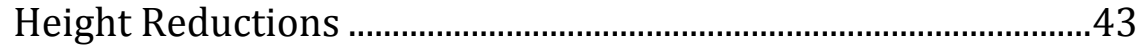

Maturity Delay.................................................................................... 44

Soybean Yield ..................................................................................

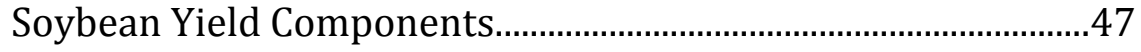

Literature Cited ......................................................................................... 
III. Investigations of Early-Season Herbicide, Fungicide, and Slow-Release Nitrogen Co-Applications in Field Corn.......................................................60

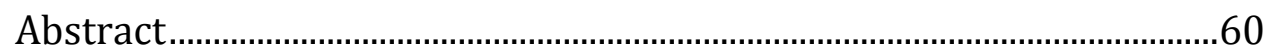

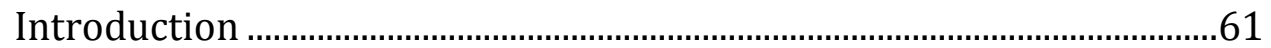

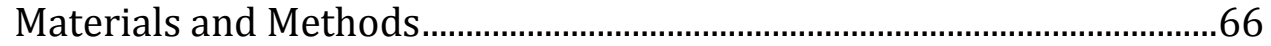

General Trial Information.............................................................66

Treatment Evaluation and Data Collection.....................................67

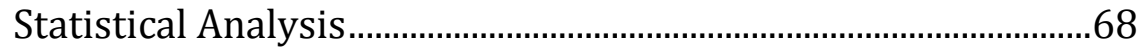

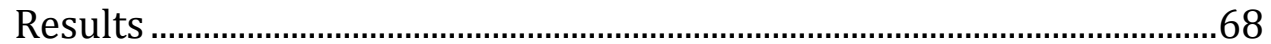

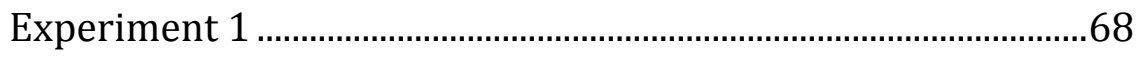

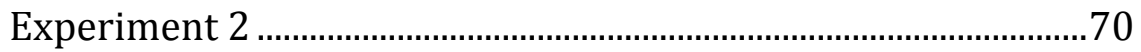

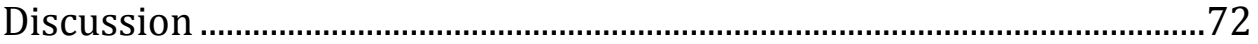

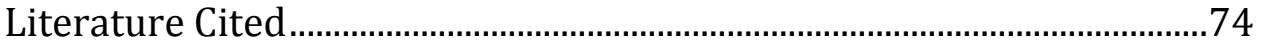




\section{LIST OF TABLES}

\section{Chapter II}

\section{Influence of Application Timings and Sub-Lethal Rates of Synthetic Auxin Herbicides on Soybean}

Table 2.1 Source of materials used in the experiment

Table 2.2 Monthly rainfall ( $\mathrm{mm}$ ) and average monthly temperatures (C) from April through October in 2011 and 2012 in comparison to the 30-yr average in Boone County, Missouri

Table 2.3 Soybean injury, rate of maturity, and height in response to eight synthetic auxin herbicides applied at the V3 and R2 stages of soybean growth combined across 2011 and 2012.

Table 2.4 Soybean yield and yield components in response to eight synthetic auxin herbicides applied at the V3 and R2 stages of soybean growth combined across 2011 and 2012 .

\section{Chapter III}

Investigations of Early-Season Herbicide, Fungicide, and Slow Release

\section{Nitrogen Co-Applications in Field Corn}

Table 3.1 Monthly rainfall ( $\mathrm{mm}$ ) and average monthly temperatures (C) from April through October in 2011 and 2012 in comparison to the 30-yr average in Boone County, Missouri

Table 3.2 Sources of materials used in the experiments ...................................... 78

Table 3.3 Analysis of variance of corn injury, corn height, and seed yield following V5 herbicide and fungicide co-applications. Studies were conducted near Columbia, MO during 2011 and 2012

Table 3.4 Influence of V5 herbicide and fungicide co-applications on injury and yield in field corn ............................................................................ 80 
Table 3.5 Analysis of variance for corn injury, corn height, and seed yield following V5 herbicide, fungicide, and $\mathrm{N}$ fertilizer co-applications.

Studies were conducted near Columbia, MO during 2011 and 2012.82

Table 3.6 Influence of V5 herbicide, fungicide, and fertilizer co-applications on injury and yield in field corn ...................................................................83 


\title{
EVALUATION OF AGROCHEMICAL INTERACTIONS AND APPLICATION TIMINGS IN CORN AND SOYBEAN
}

\author{
Craig B. Solomon \\ Dr. Kevin W. Bradley, Thesis Supervisor
}

\begin{abstract}
Due to the increase in glyphosate-resistant (GR) weeds, two agrochemical companies have developed soybeans with resistance to 2,4-D and dicamba in an effort to provide growers with new options for the control of problematic GR species. Due to the high sensitivity of non-transformed soybeans that may be grown in close proximity to 2,4-D- or dicamba-resistant crops, there is increasing concern about the potential for off-target movement of these herbicides through drift, volatility, and/or tank contamination. Traditionally, applications of fungicides have been made to corn between tasseling (VT) and silking (R1); however in recent years some pesticide manufacturers have promoted early-season fungicide coapplications with post-emergence (POST) herbicide treatments. Corn is also a nitrogen-demanding crop, where nitrogen uptake is often limited due to soil characteristics and environmental factors. The ability to co-apply agrochemicals allows growers the option of combining desirable products with a POST herbicide application at no additional application cost. The objectives of this research are to: 1) compare the relative soybean phytotoxicity of eight synthetic auxin herbicides to one another and 2) determine the effects of V5 herbicide, fungicide, and/or slowrelease $\mathrm{N}$ co-applications on corn injury and yield. Results from these experiments suggest significant yield reductions can occur if proper application methods are not followed when applying synthetic auxin herbicides. Also, the addition of a fungicide


and/or slow-release $\mathrm{N}$ fertilizer at V5 is not likely to increase corn grain yields in comparison to an herbicide treatment alone. 


\section{CHAPTER I}

\section{LITERATURE REVIEW}

\section{JUSTIFICATION}

Farm expenditures have continued to increase steadily in recent years. In 2007, farm expenses rose 9.3\% from 2006 and in 2008, expenses grew by another 8.3\%. In 2011, farm production expenditures in the United States were estimated at $\$ 318.7$ billion, up from $\$ 289.1$ billion in 2010 . These increases are in direct response to increased costs for fuel, fertilizers, and pesticides (USDA 2008; USDA 2009; USDA 2012). Due to rising production costs, farmers have adopted reduced or no-tillage systems, which can provide both environmental and economic benefits. This widely adopted farming technique allows farmers to reduce fuel, labor, and machinery costs while reducing soil erosion (Doran et al. 1984; Gebhardt et al. 1985). With these no-tillage systems in place, farmers use non-selective pre-plant (PP) and residual herbicide programs to be able to plant into clean, weed-free fields, which allows the crop to gain a competitive advantage over weeds (Krausz et al. 1993). A major contributor to the adoption of no-tillage systems was the release of glyphosate in the early 1970's, which allowed broad spectrum weed control with a pre-emergent burndown application (Woodburn 2000). In 1996, glyphosateresistant (GR) soybean (Glycine max L.) were introduced, allowing growers to apply glyphosate directly to their crop for season-long weed control. In the United States, GR soybean hectares increased from 13\% in 1996 to over 90\% in 2008 (Duke and Powles 2009). Unfortunately, the widespread adoption of this technology resulted 
in an overuse of glyphosate, leading to the selection of weed populations that are resistant to this herbicide (Heap 2012). Currently there are 14 weeds known to be resistant to glyphosate in the United States, including: annual bluegrass (Poa annua L.), common ragweed (Ambrosia artemisiifolia L.), common waterhemp (Amarathus rudis Sauer.), giant ragweed (Ambrosia trifida L.), goosegrass (Eleusine indica L. Gaertn.), hairy fleabane (Conyza bonariensis L. Cronq.), horseweed (Conyza Canadensis L. Cronq.), Italian ryegrass (Lolium multiflorum Lam. Husnot), johnsongrass (Sorghum halepense L. Pers.), junglerice (Echinochloa colona L. Link.), kochia (Kochia scoparia L. Schrad.), palmer amaranth (Amaranthus palmeri S. Wats.), rigid ryegrass (Lolium rigidum Gaudin.), and spiny amaranth (Amaranthus spinosus L.) (Heap 2012).

Due to the negative impact of GR weeds, several agrochemical companies have developed new technologies that should provide growers with new options for the control of these species. Currently, Dow AgroSciences and Monsanto are developing soybean, corn (Zea mays L.), and cotton (Gossypium hirsutum L.) varieties with traits that confer resistance to pre-plant (PP) and post-emergence (POST) applications of the synthetic auxin herbicides 2,4-dichlorophenoxy acetic acid (2,4-D) and dicamba, respectively. Due to the high sensitivity of nontransformed soybean that may be grown in close proximity to 2,4-D- or dicambaresistant crops, there is increasing concern about the potential for off-target movement of these herbicides through drift, volatility, and/or tank contamination. This research will be conducted to better understand the differing sensitivities of soybean to synthetic auxin herbicides. 
The ability to co-apply agrochemicals allows growers the option of combining desirable agrochemical products with a POST herbicide application at no additional application cost. From 1972 through 2005, the average corn price was approximately $\$ 0.08 \mathrm{~kg}^{-1}$. By 2009 , corn prices were averaging about $\$ 0.20 \mathrm{~kg}^{-1}$ (USDA 2010). Several factors have influenced this, including expanding global markets and the United States legislation which promotes the use of biofuels made from corn. With the record-high commodity prices, certain precautionary inputs may be more attractive to growers. With the increased adoption of reduced-tillage and continuous corn systems, the residues left on the soil surface can serve as a source of inoculum for foliar diseases. In response, many producers have made lateseason fungicide applications a routine practice in corn production. As corn prices have continued to increase, fungicide manufacturers have begun to promote fungicide applications at earlier growth stages (V5-V6) in combination with a POST herbicide application. Corn is also a nitrogen-demanding crop, where nitrogen $(\mathrm{N})$ uptake is often limited due to soil characteristics and environmental factors (Lipiec and Stepniewski 1995). Foliar applications of $\mathrm{N}$ have been shown to be an effective method of $\mathrm{N}$ fertilization for grain crops and other plants (Finney et al. 1957). Applications of slow-release N products could coincide with early-season POST herbicides in corn, exploiting the use of inputs with no additional application costs (Paniagua 2006). The objectives of this research are to: 1) compare the relative soybean phytotoxicity of eight synthetic auxin herbicides to one another and 2) determine the effects of V5 herbicide, fungicide, and/or slow-release $\mathrm{N}$ coapplications on corn injury and yield. 


\section{INTRODUCTION}

\section{Synthetic Auxin Herbicides}

\section{History and Development}

With the introduction of the synthetic auxin herbicides 2,4-D and 2-methyl4-chlorophenoxyacetic acid (MCPA) subsequent to World War II, a new era of weed control began in modern crop production. Due to their selectivity to dicotyledonous weeds and systemic mobility within the plant, the synthetic auxinic herbicides proved highly valuable for weed control in cereal crops, pastureland, rangeland and turfgrass (Kirby 1980). Prior to this development, dicotyledonous weeds resulted in substantial yield losses when not controlled by intensive hand removal or tillage methods. For the first time, producers were able to effectively control broadleaf weeds both pre-emergence (PRE) and POST with a fairly inexpensive herbicide application. In 1992, Burnside et al. evaluated the impacts of auxinic herbicides and reported that the sale of these products was approximately $\$ 171$ million, with the loss of these chemistries resulting in an annual increase in alternative herbicide and non-chemical weed control costs of $\$ 947$ million (Burnside et al. 1996).

The origins of the concept of plant hormones can be traced to the late 19th century, when the famous German botanist, Julius Von Sachs proposed the existence of mobile endogenous compounds that regulate plant growth and organ formation (Thimann 1977). This theory corresponded with a study by Charles and Frances Darwin, as described in their 1880 book, where they grew grass seedlings in lateral light to demonstrate the existence of a transported signal that mediates plant 
phototropism (Darwin 1880). During the century that followed, this signal was shown to be indole-3-acetic acid (IAA/auxin), the first known plant hormone.

Once the chemical structure of IAA was identified, synthetic compounds with similar structures were developed and tested for auxinic activity (Kelley and Riechers 2007; Sterling and Hall 1997). By the 1940's an array of IAA-derived compounds had been synthesized, including 1-napthalene acetic acid (1-NAA), MCPA, and 2,4-D (Grossman 2010). At low doses, these derivatives of IAA exhibit similar biochemical and physiological effects as their natural precursor (Sterling and Hall 1997). The structures of these synthetic auxin herbicides are similar to IAA, depending on the position of their carboxylic acid and type of functional groups that the derivative possesses (Ashton and Crafts 1981). The essential structural requirement for their activity is a strong negative charge on the carboxyl group of the dissociated molecule, which is separated from a weaker positive charge on the planar aromatic ring, with a distinct distance (Grossmann 2003; Farrimond et al. 1978; Grossmann 2007). The synthetic auxin herbicides developed to date can be generally categorized into four main classes; the phenoxyalkanoic acids (e.g. 2,4-D, MCPA), benzoic acids (e.g. dicamba, chloramben), pyridine carboxylic acids (e.g. picloram, triclopyr, clopyralid, aminopyralid, fluroxypyr) and quinoline carboxylic acids (e.g. quinclorac and quinmerac) (Sterling and Hall 1997; Mithila et al. 2011).

The ability of the synthetic auxin herbicides to cause similar plant responses as IAA, although longer-lasting and much stronger in intensity, is due to their higher stability when inside the plant (Grossmann 2007). Natural auxin is a fairly simple compound, and can be rapidly inactivated by conjugation and/or direct oxidation 
through multiple pathways within the plant (Woodward and Bartel 2005).

Alternatively, synthetic auxins are much more stable and longer-lasting, as they are not inactivated within the plant as readily. Synthetic auxin herbicides, when present at the cellular sites of action, stimulate a variety of growth and developmental processes similar to IAA. However, with increasing concentrations within the plant, either from synthetic auxins or natural IAA, growth via cell division and subsequent vascular arrangement can be disrupted, resulting in lethal consequences (Grossman 2010). These growth abnormalities can result in symptoms ranging from stem/petiole/leaf epinasty and leaf cupping, to thickening/calloused stems and roots, and ultimately chlorosis and necrosis (Kelley and Riechers 2007). The lack of phytotoxicity of these herbicides to grasses and non-sensitive dicots has been linked to several factors, including metabolism to non-phytotoxic molecules, vasculature anatomy differences, and target-site insensitivity to the auxinic compound (Grossman 2010; Sterling and Hall 1997).

The sequence of events leading to plant death after application of a synthetic auxin herbicide has been described as an auxin overdose, which is characterized by sensitive plants "growing themselves to death" (Gilbert 1946; Grossman 2010). This is consistent with the plants loss in regulation of cell division, patterning, and expansion, resulting in the breakdown of the vascular infrastructure and the inability to transport water, sugars, nutrients, hormones, etc. Additionally, the rapidly forming meristematic tissues act as metabolic sinks, resulting in the mobilization of sugars and proteins out of functional tissues and into new tissues, which have to senesce to accommodate these new demands (Grossmann 2003). 
More recently, research indicates that sensitive plants also accumulate ethylene, abscisic acid (ABA), and reactive oxygen species (ROS) following application of synthetic auxin herbicides (Grossman 2010; Mithila et al. 2011).

\section{Volatility and Spray Drift Concerns}

Volatility and vapor drift have been negatively associated with synthetic auxin herbicides since their development. Spray drift is largely determined by wind speed and direction, atmospheric conditions, spray equipment, droplet size, boom height, and method of application (Auch and Arnold 1978; Al-Khatib and Peterson 1999; Egan and Mortensen 2012; Wax et al. 1969; Wolf et al. 1993). Tayler and Spencer (1990) have noted volatilization losses of $80-90 \%$ within a few days after application, depending on weather conditions and management practices. Wolf et al. (1993) found that high winds, lower carrier volumes, finer sprays, $110^{\circ}$ tips, and un-perforated shields resulted in decreased spray uniformity. The same study showed that when all other factors are equal, 8002 tips at $100 \mathrm{~L} \mathrm{ha}^{-1}$ can result in $65 \%$ less drift than 8001 tips with a spray volume of $50 \mathrm{~L} \mathrm{ha}^{-1}$ (Wolf et al. 1993). Additionally, the formulation of a particular herbicide can have a dramatic effect on volatilization. For example, the acid form of dicamba is more volatile than the amine salt formulation (Green and Owen 2011).

Due to the diversity of cropping systems in the United States, it is not uncommon for crops that are more tolerant of synthetic auxin herbicides to be grown in close proximity to crops that are more susceptible to these herbicides, and often in rotation with one another (Wax et al. 1969). Thus, off-target movement can become a major concern due to the widespread use of 2,4-D, dicamba, picloram, 
triclopyr, and clopyralid in controlling emerged broadleaf weeds in corn, sorghum (Sorghum bicolor L. Moench), small grains, fallow land, turf, pasture, and rangeland. Injury to susceptible plants from off-target movement of synthetic auxins has been well documented in many crops, including cotton (Everitt and Keeling 2009; Johnson et al. 2012; Marple et al. 2007), alfalfa (Medicago sativa L.) (Al-Khatib et al. 1992), common sunflower (Helianthus annuus L.) (Derksen 1989; Lanini 2000), peanut (Arachis hypogaea L.) (Johnson et al. 2012), wine grape (Vitis vinifera L.) (AlKhatib et al. 1993), and many other crops (Derksen et al. 1989; Hemphill and Montgomery 1981; Lanini 2000). As a result, certain states have laws that declare which synthetic auxin herbicides can be applied, the chemical formulation, and at what time of the year (ASPB 2012; Texas Agriculture Code 1984).

\section{Yield Reductions}

Soybeans are especially at risk of injury from off-target movement of synthetic auxin herbicides due to their similar geographic proximity and rotation with monocot crops (Wax et al. 1969). Al-Khatib and Peterson (1999) evaluated soybean response to reduced rates of dicamba and other herbicides being applied at the V2-V3 growth stage. In 1997 and 1998, $187 \mathrm{~g} \mathrm{ha}^{-1}$ of dicamba (33\% of the labeled use rate in corn) resulted in yield reductions of 92 and $80 \%$, respectively. In the same study, $56.1 \mathrm{~g} \mathrm{ha}^{-1}$ of dicamba ( $10 \%$ of the labeled use rate in corn) resulted in yields $45 \%$ less than the control (Al-Khatib and Peterson 1999). Andersen et al. (2004) found that when $5.6 \mathrm{~g} \mathrm{ha}^{-1}$ of dicamba (1\% of the labeled use rate in corn) was foliar-applied to soybeans at the V3 growth stage, yield reductions of 14 to $34 \%$ were observed. The same study reported that it took foliar applications of $112 \mathrm{~g}$ ha- 
${ }^{1}$ of $2,4-\mathrm{D}$ amine ( $20 \%$ of the labeled use rate in corn) applied at the same stage, to observe similar yield reductions (Andersen et al. 2004). In a similar study, Kelley et al. (2005) observed dicamba applications of 0.56 and $5.6 \mathrm{~g} \mathrm{ha}^{-1}$, to V3 soybean resulted in yield reductions of 7 and 6\% respectively, with 2,4-D applications losing 6 and $25 \%$ of yield when 56 and $180 \mathrm{~g} \mathrm{ha}^{-1}$ were applied, respectively (Kelley et al. 2005). Applications at the R2 stage of growth resulted in yield reductions of 0 and $7 \%$ for 0.56 and $5.6 \mathrm{~g} \mathrm{ha}^{-1}$ of dicamba, and 2 and $15 \%$ for 56 and $180 \mathrm{~g} \mathrm{ha}^{-1}$ of 2,4-D (Kelley et al. 2005). In the same study, clopyralid was applied at 2.1 and $6.6 \mathrm{~g} \mathrm{ha}^{-1}$ to both V3 and R2 soybeans, resulting in yield reductions of 9 and $15 \%$ for the V3 applications, and 0 and $12 \%$ for the R2 applications (Kelley et al. 2005). With the exception of $5.6 \mathrm{~g} \mathrm{ha}^{-1}$ of dicamba, all treatments evaluated showed lower yield reductions when applied at the $\mathrm{R} 2$ stage of growth (Kelley et al. 2005). This is in contrast to previous literature that reported greater injury and yield reductions when dicamba was applied at later soybean growth stages (Wax et al. 1969; Auch and Arnold, 1978). Wax et al. (1969) determined that approximately $16.7 \mathrm{~g} \mathrm{ha}^{-1}$ of dicamba applied to soybeans at the pre-bloom and bloom growth stages resulted in yield reductions of 11 and 49\%, respectively, with 2,4-D resulting in no yield losses. In the same study, $8.75 \mathrm{~g} \mathrm{ha}^{-1}$ of picloram applied to soybeans at the same growth stages resulted in yield reductions of 18 and 98\%, respectively (Wax et al. 1969). The sensitivity of soybeans to dicamba and 2,4-D was also documented in Minnesota by comparing the number of soybean drift injury incidents. In 1974, even with 2,4-D being applied to over three times as many hectares of corn as dicamba, 68 soybean drift incidents were reported for dicamba compared to seven 
from 2,4-D (Behrens and Lueschen 1979). Conversely, Marple et al. (2007) observed the opposite phenomenon in cotton, where $5.6 \mathrm{~g} \mathrm{ha}^{-1}$ of 2,4-D amine (1\% of the labeled use rate in corn) applied at the six- to eight-leaf growth stage of cotton resulted in yield reductions of 90 to $100 \%$. At the same growth stage and rate, a foliar application of dicamba resulted in 0 to $19 \%$ yield reductions, illustrating the diversity of broadleaf crop sensitivities to various synthetic auxin herbicides (Marple et al. 2007).

\section{Height Reductions}

Auch and Arnold (1978) observed that the greatest soybean height reductions from dicamba applications were made at the early-bloom stage, as compared to applications made at vegetative growth stages or from mid-bloom through late-pod. The authors also noted that dicamba applied at V1-V2 severely damaged/killed the apical bud, inducing branching and subsequent height recovery (Auch and Arnold 1978). Kelley et al. (2005) also noted that dicamba, 2,4-D, and clopyralid reduced soybean height when applied at late vegetative stages (V7) as compared to V3 or R2. Wax et al. (1969) also found that dicamba and picloram reduced soybean height more at the late vegetative growth stages (V8/early-bloom) than similar applications at earlier growth stages (V3/pre-bloom).

\section{Delayed Maturity}

Delayed maturity of soybeans following exposure to synthetic auxin herbicides has also been documented in a number of previous experiments (Auch and Arnold 1978; Kelley et al. 2005; Wax et al. 1969). Wax et al. (1969) observed greater maturity delay when dicamba and picloram were applied during the 
reproductive stages, as compared to the earlier vegetative stages. When picloram was applied at $8.75 \mathrm{~g} \mathrm{ha}^{-1}$ to soybean in the pre-bloom and bloom growth stages, soybean maturity was delayed 2 and 27 days, respectively (Wax et al. 1969). Dicamba applied at $16.7 \mathrm{~g} \mathrm{ha}^{-1}$ to soybean in the pre-bloom and bloom growth stages resulted in delays in maturity of 4 and 14 days, respectively (Wax et al. 1969). Auch and Arnold (1978) also observed a delay in soybean maturity from foliar applications of dicamba throughout the reproductive growth stages. When comparing early-bloom, mid-bloom, early-pod, and late-pod dicamba applications, most rates and applications resulted in additional delays in maturity as soybean further developed (Auch and Arnold 1978).

\section{Visual Symptomology}

Visual injury associated with synthetic auxin herbicides has been reviewed and explained extensively. Common symptomologies include leaf cupping, stem/leaf epinasty, cracked/swollen stems, leaf drawstring effect, as well as chlorosis and necrosis (Auch and Arnold 1978; Kelley et al. 2005; Sciumbato et al. 2004a; Wax et al. 1969; Andersen et al. 2004; Al-Khatib and Peterson 1999). Kelley et al. (2005) described that dicamba applications to soybean resulted in new trifoliate leaves being cupped and crinkled, "with higher rates resulting in smaller leaves and reduced overall growth compared to lower rates". Symptoms associated with 2,4-D included epinasty of leaves/stems and swollen/cracked stems (Kelley et al. 2005). Clopyralid injury was noted as similar to dicamba, but with "more thin, strapped leaves with parallel venation and less cupping injury" (Kelley et al., 2005). Wax et al. (1969) described 2,4-D injury as "strapping, puffing, and ruffling of the 
leaves", with dicamba and picloram causing cupping and crinkling of the leaves. The authors also noted that pre-bloom applications of dicamba resulted in significant branching in the cotyledon and unifoliate axils, with the majority of branching induced where the terminal bud was killed (Wax et al. 1969). Similar visual symptomologies associated with synthetic auxin herbicides have also been described in reference to many other broadleaf crops and vegetables (Al-Khatib et al. 1992; Al-Khatib et al. 1993; Everitt and Keeling 2009; Hemphill and Montgomery 1981; Lanini 2000; Sciumbato et al. 2004b).

\section{Herbicide-Resistance and New Crop Developments}

As of $2012,93 \%$ of soybean hectares planted in the United States were genetically-engineered, herbicide-resistant varieties (USDA 2012). Due to the increase in the occurrence of glyphosate-, protoporphyrinogen oxidase- (PPO) and acetolactate synthase/acetohydroxyacid synthase- (ALS/AHAS) resistant weed populations, several new herbicide-resistant crop offerings are expected to be introduced onto the marketplace in the near future. Among these are soybean that have been genetically modified to withstand applications of either 2,4-D (Wright et al. 2010b) or dicamba (Behrens et al. 2007). Following an extensive use history of 2,4-D and dicamba over the past 50 years, weeds with resistance to these herbicides have been slow to evolve. To date, only 24 weed species in the world have been characterized with resistance to at least one of the members in the synthetic auxin herbicide family (Heap 2012). Specifically, there have been 18 species characterized with resistance to 2,4-D, and 6 with resistance to dicamba (Heap 2012). The Weed Science Society of America defines herbicide resistance as "the 
inherited ability of a plant to survive and reproduce following exposure to a dose of herbicide normally lethal to the wild type. In a plant, resistance may be naturally occurring or induced by such techniques as genetic engineering or selection of variants produced by tissue culture or mutagenesis" (WSSA 2011). Resistance is prone to develop with herbicides that have a single target site, a specific mode of action, are highly toxic to a wide range of target species, are persistent in the soil, are applied frequently in one season and/or are used alone repeatedly for several years (LeBaron and McFarland 1990). Thus, synthetic auxin herbicides that have multiple sites of action and have relatively low soil persistence may be less prone to resistance than other herbicide classes. Most cases involving resistance to synthetic auxin herbicides were associated with continuous applications of a single product over many years, leading to extreme selection pressure in these specific environments (Cranston et al. 2001; Heap and Morrison 1992; Holt and LeBaron 1990).

The aryloxyalkanoate dioxygenase enzymes (AADs) derived from common soil bacteria can effectively degrade 2,4-D, triclopyr, and fluroxypyr, as well as aryloxyphenoxypropionate graminicides such as quizalofop and cyhalofop (Wright et al. 2010b). The AAD enzymes can be divided into AAD-1 from Sphingobium herbicidovorans which codes for an enzyme that metabolizes 2,4-D as well as ACCase-inhibiting herbicides and AAD-12 from Delftia acidovorans which codes for an enzyme that not only metabolizes phenoxyalkanoic acids, but also certain pyridine carboxylic acids such as triclopyr and fluroxypyr (Wright et al. 2010a, 2010b). Selected soybean plants containing the $A A D-12$ gene were resistant to rates 
of 2,4-D greater than $4.48 \mathrm{~kg}^{2}$ ae ha-1 (eight times the labeled use rate in corn) when applied at the V3 growth stage (Wright et al. 2010b). These transgenic 2,4-Dresistant soybeans were also able to withstand both PRE and POST applications of 2,4-D, with a seasonal total of $3.36 \mathrm{~kg}$ ae ha-1 2,4-D (Wright et al. 2010b). Additionally, the transgenic soybeans were noted as performing agronomically similar (i.e., date to flowering, lodging, phenotype, and yield) as the untransformed control variety (Wright et al. 2010b).

As of $2012,73 \%$ of corn hectares planted in the United States were genetically engineered herbicide-resistant (21\%) or "stacked gene" varieties (52\%), that include both insect and herbicide resistant traits (USDA 2012). Although 2,4-D and dicamba have been widely used in corn production for broadleaf weed control, applications nearing tassel emergence are restricted due to plant malformations, stalk strength weaknesses, and possible yield reductions. Inserting the previously described $A A D$-1 gene into maize was logical to provide options for late-season control of troublesome broadleaf weeds, and control of grass weeds with a new herbicide having a different mechanism of action not currently utilized in corn production. Successful transformations were made with resulting lines with increased tolerance to both 2,4-D and quizalofop (Wright et al. 2010b). Selected lines showed tolerance of 2,4-D up to $4.48 \mathrm{~kg}$ ae ha-1 and to $0.28 \mathrm{~kg}^{\mathrm{ae} \mathrm{ha}}{ }^{-1}$ of quizalofop (Wright et al. 2010b). The new lines exhibited equivalent agronomic performance (i.e. date to silking, date to pollination, date to maturity, lodging, phenotype, and yield) as the untransformed control variety (Wright et al. 2010b). Corn, soybean, and cotton varieties expressing AAD genes, as well as at least one 
other existing herbicide-resistant trait, are expected to be introduced onto the marketplace by 2014 (Wright et al. 2010b).

Dicamba-resistant soybeans have been developed by Monsanto through the use of a soil bacterium, Pseudomonas maltophilia (strain DI-6), which naturally converts dicamba to herbicidally-inactive 3,6-dichlorosalicylic acid (DCSA) and other products (Behrens et al., 2007; Herman et al. 2005). This conversion is facilitated by a three-component enzyme dicamba $O$-demethylase, which is comprised of a ferredoxin, a reductase, and a monooxygenase (Herman et al. 2005). Instead of having to encode all three enzymes, researchers learned they could link dicamba monooxygenase (DMO) with an upstream chloroplast transit peptide, which indirectly provides the necessary functions of the ferredoxin and reductase components necessary for dicamba degredation (Behrens et al. 2007; Cao et al. 2011; Herman et al. 2005). Transgenic soybeans that expressed this DMO gene have been noted as exhibiting resistance to foliar applications of dicamba up to $5.6 \mathrm{~kg}$ ae ha $^{-1}$ (Behrens et al. 2007). Field evaluations of these transgenic soybeans have revealed complete resistance to dicamba PP and vegetative stage applications of 2.8 $\mathrm{kg}$ ae ha-1, with equivalent agronomic performances (date to flowering, height, lodging, and yield) as the untransformed control variety (Behrens et al. 2007). In a similar fashion to Dow AgroSciences with their AAD genes, Monsanto has also identified the value of the DMO trait expression in corn. Although corn is naturally tolerant to dicamba, climactic conditions and application timing intervals restrict certain applications that could prove valuable in a corn production system. Successful transformants of corn with the DMO gene were noted to be tolerant to 
PRE and POST applications of dicamba at 6.7 and $27 \mathrm{~kg}$ ae ha-1, respectively (Cao et al. 2011). These rates are 12 and 48 times the currently labeled recommended use rate of dicamba in corn. Commercial varieties expressing the DMO trait, as well as at least one other herbicide-resistant trait, are expected in corn, soybeans and cotton by 2015 (Green and Owen 2011).

Together these new developments coupled with existing genetically modified (GM) varieties will provide producers with a variety of options for the control of herbicide-resistant weed biotypes. Although these new technologies have their obvious benefits, extensive care will be required in all aspects of herbicide application. As noted, off-target movement of these herbicides has been a major concern, leading both companies to develop new formulations of their respective products (Green and Owen 2011). Even with volatility and drift minimized, tank contamination of 2,4-D and dicamba remains a significant concern. Synthetic auxin herbicides are known to adhere to the plastic and rubber parts inside spray tanks, and are usually not sufficiently cleansed by water alone (Steckel et al. 2005).

\section{Herbicide-Agrochemical Co-Applications in Corn}

\section{Fungicide Applications}

In 2012, approximately 39 million hectares of corn were planted across the United States (USDA 2012). In the Corn Belt, several foliar diseases have been shown to reduce yield, including gray leaf spot (Cercospora zeae-maydis Tehon \& E.Y. Daniels), northern leaf blight (Exserohilum turcicum (Pass.) K.J. Leonard \& E.G.

Suggs, syn. Helminthosporium turcicum Pass.), southern corn rust (Puccinia polysora Underw.), common rust (Puccinia sorghi Schwein), eyespot (Aureobasidium zeae 
(Narita \& Hiratsuka) J.M. Dingley, syn. Kabatiella zeae Narita \& Hiratsuka), northern leaf spot (Bipolaris zeicola (G.L. Stout) Shoemaker, syn. Helminthosporium carbonum Ullstrup), and others (Wegulo et al. 1997; Wise and Mueller 2011). Yield reductions due to these diseases occur from the loss of photosynthetic leaf area due to blighting, as well as a loss in radiation use efficiency that can hinder the translocation of photosynthates during grainfill (Ward et al. 1997b; Ward and Nowell 1998; Wegulo et al. 1997). When applied in the proper manner, foliar fungicides can provide control of these diseases (Ward et al. 1997a; Wegulo et al. 1998).

In the U.S., yield reductions associated with gray leaf spot (GLS) have ranged from 0 to 100\% (Donahue et al. 1991; Hilty et al. 1979; Jenco 1995; Latterell and Rossi 1983; Wegulo 1994). Yield losses due to GLS are a function of the infection time/duration, growth stage of crop, weather conditions during grainfill, hybrid susceptibility/maturity, and yield potential of the hybrid (Hilty et al. 1979; Latterell and Rossi 1983; Ward and Nowell 1998).

Even with economic analyses that provide producers with information about profitable fungicide applications (Munkvold et al. 2011; Paul et al. 2011; Wegulo et al. 1997), decisions on when and where to apply fungicides are still predominantly subjective (Wegulo et al. 1997). Wise and Mueller (2011) compiled information from 39 published trials between 2000 and 2010 that examined the effectiveness of fungicides on hybrid dent corn to assess the likelihood of yield increases following fungicide applications. In 18 of the 39 trials (46\%) they reported significant effects on corn yield. After pooling the 39 trial treatments into a common dataset and 
selecting only trials that included foliar disease assessments, approximately $80 \%$ of the 472 treatments had a positive yield response from a fungicide application (Wise and Mueller 2011). Since a positive yield response from the additional input does not necessarily relate to a positive economic benefit, the authors determined that $48 \%$ of the 472 treatments resulted in a yield response that met or exceeded their economic break-even value of $377 \mathrm{~kg} \mathrm{ha}^{-1}$ (Wise and Mueller 2011). According to data from Illinois, if at least 15\% of ear leaf area is affected by disease at the end of the season, a foliar fungicide applied between VT and R1 would most likely be economically beneficial (Bradley 2012).

Historically, foliar fungicide applications have proven profitable in seed corn production, where the crop value can be 10 times higher than in grain production (Munkvold et al. 2011; Paul et al. 2011; Shaner et al. 1999; Wegulo et al. 1997; Wegulo et al. 1998). Relatively high product and application costs, combined with the uncertainty of disease pressure and subsequent yield loss, have historically made fungicide applications in grain production rare. However, due to recent corn prices, increased conservation-tillage methods that lead to greater disease potential, and industry claims of substantial yield increases with new fungicides, the use of foliar fungicides on field corn has increased dramatically over the past five years (Paul et al. 2011). Also, fungicides have shown beneficial physiological effects in crops regardless of disease pressure, further increasing the possibility of profitable fungicide applications (Bradley and Ames 2010).

Traditionally, applications of these fungicides have been made to corn between tasseling (VT) and silking (R1); however in recent years some pesticide 
manufacturers have promoted early-season fungicide co-applications with postemergence herbicide treatments (Robertson 2010). To date, little research has been published on the efficacy or value of early-season (V4-V7) fungicide applications to corn. Though this early application of fungicide may "protect" yield, it is predominately thought of as a supplement to the tasseling application, not a replacement (Robertson 2010). Potential benefits of such applications include the ability to co-apply fungicides with a POST herbicide application, eliminating increased application costs. On the contrary, most of the economically-important foliar diseases that affect corn are either not present at this "early-stage" or at very low levels (Bradley 2010). Furthermore, unnecessary fungicide applications should be minimized, as many fungicide classes have already been documented as high-risk for the development of resistance in fungal species (Barlett et al. 2002).

Data that has been reported from foliar fungicide trials on corn is highly variable and inconsistent. A survey that compared V6 and VT-R1 fungicide applications across eight studies from multiple states resulted in an average yield response of $94 \mathrm{~kg} \mathrm{ha}^{-1}$ with V6 applications and $502 \mathrm{~kg} \mathrm{ha}^{-1}$ with VT-R1 applications (Bradley 2010). One study in Iowa found little justification for a V6 foliar fungicide application, either alone or in combination with a VT-R1 application (Robertson 2010). In a similar study investigating foliar fungicides at V5, R1, and R2 over 6 locations, there were no significant positive yield responses to any fungicide applications, and none of the V5 fungicide applications had an effect on foliar disease severity (Robertson et al. 2012). In this same study, one of 6 locations 
exhibited significantly lower stalk rot severity with V5+R1 fungicide applications compared to the nontreated control (Robertson et al. 2012).

\section{Foliar Fertilization}

Corn is a nitrogen-demanding crop and nitrogen (N) uptake is often limited in poorly-drained claypan soils, or in fields where losses from denitrification, volatilization, and/or leaching are more likely to occur (Lipiec and Stepniewski 1995). Noellsch et al. (2009) found that the targeted use of slow-release N products across claypan landscapes could increase grain yields and profitability compared to conventional $\mathrm{N}$ fertilizers. The timing of these slow-release $\mathrm{N}$ products could coincide with early-season applications of POST herbicides in corn, again exploiting the use of inputs with no additional application costs (Paniagua 2006).

Soil applications are the most common and effective method of supplying N, and other macronutrients to crops (Fageria et al. 2009). In this method, soil-applied nutrients are absorbed by the roots, and translocated throughout the plant. However, foliar applications of urea $\left(\mathrm{CH}_{4} \mathrm{~N}_{2} \mathrm{O}\right)$ have also been shown to be an effective method of nitrogen fertilization for grain crops from as early as the 1950's (Finney et al. 1957). Some producers find foliar applications a more attractive option for their operation due to the rapid absorption and efficient utilization of the applied nutrients (Kannan and Charnel 1986), and because a relatively quick solution can be obtained to the visible nutrient deficiencies. The ability of plants to absorb mineral nutrients when applied as foliar sprays is highly variable and dependent on a number of factors, including nutrient concentration and formulation, environment, crop timing/maturity, and soil characteristics (Boynton 
1954; Foy et al. 1953; Hanway 1962; Harder et al. 1982; Kannan and Charnel 1986; Mahmoodi et al. 2011; Sarakhsi et al. 2010).

Foliar-applied $\mathrm{N}$ has been shown to increase nutrient content in the grain of wheat (Finney et al. 1957), soybean (Boote et al. 1978), and corn (Harder et al. 1982; Jung et al. 1972; Kargbo 1978). However, even with increases in nutrient concentrations, yields have been shown to be equal, or less than the control (Below et al. 1984; Harder et al. 1982; Kargbo 1978). Though Garcia and Hanway (1976) reported significant soybean yield increases in response to applications of balanced $\mathrm{N}, \mathrm{P}, \mathrm{K}$, and S solutions during grain fill, Boote et al. (1978) observed that foliar applicatioins of $\mathrm{N}, \mathrm{P}, \mathrm{K}$, and $\mathrm{S}$ to soybeans resulted in less yield than the nontreated control. Sesay and Shibles (1980) also reported no yield response from foliar applications of N, P, and $\mathrm{K}$ in two soybean cultivars. In regards to corn, a variety of reports have shown significant yield increases from POST N applications at V5 up to tasseling (Binder et al. 2000; Jung et al. 1972; Nelson et al. 2010; Randall et al. 1997; Scharf et al. 2002).

One of the main issues associated with foliar $\mathrm{N}$ applications is the resulting leaf injury caused by any sizeable quantity of $\mathrm{N}$ applied (Foy et al. 1953). When fertigation is an option, the ability of dilution allows minimal crop injury (Gascho et al. 1984; Jung et al. 1972). Nelson et al. (2010) evaluated rescue N applications to corn from $\mathrm{N}$ sources either broadcasted or applied between-row (BR). Their results indicated that when ammonium nitrate or urea-ammonium nitrate was broadcast on corn, leaf injury resulted in reduced yield compared with a BR application (Nelson et al. 2010). When comparing broadcast and BR applications, minimal 
injury and equivalent yields were observed from urea or urea plus $N$-(n-butyl) thiophosphoric triamide (Nelson et al. 2011). Many authors have hypothesized that losses in leaf area due to the burning and necrotic spots from the fertilizer salts is at least partly responsible for the lack of positive yield responses (Below et al. 1984; Boote et al. 1978; Foy et al. 1953; Harder et al. 1982; Nelson et al. 2010). Gamble and Emino (1987) examined the morphological characteristics associated with corn leaf burn from urea, and concluded the visual damage appeared to be related to water loss since the epidermal and mesophyll cells became desiccated. Bremner (1995) explained that the leaf burn following urea applications was a result of an accumulation of toxic amounts of urea in the leaves, rather than formation of toxic amounts of $\mathrm{NH}_{3}$ through hydrolysis of urea by leaf urease. Limited research has been done to investigate the effects of POST herbicide and slow-release N fertilizers on corn leaf injury and yield. The addition of a well formulated (minimal leaf burn) N-product to a POST herbicide application could be beneficial if soil and environmental properties were limiting $\mathrm{N}$ use efficiency and uptake.

\section{SUMMARY AND OBJECTIVES}

Over the past decade, corn and soybean prices have risen to historic levels. Due to increased weed resistance to herbicides, new GM traits are being developed for use in corn, soybeans, and cotton that will likely increase the number of applications of the synthetic auxin herbicides 2,4-D and dicamba in future crop production systems. The misapplication of these herbicides, either directly through tank contamination or indirectly through volatilization and/or drift, may result in significant injury to non-transformed soybean varieties. Understanding the unique 
symptomologies and implications of such misapplications will prove valuable in the diagnosis of the particular herbicide applied and subsequent yield reductions that are likely to result.

In current crop production systems where higher commodity prices are now being realized, more emphasis is being placed on maximizing yield. Additional inputs are more economically attractive and the ability to co-apply agrochemicals, such as fungicides and foliar fertilizers, with an already planned POST herbicide application, may be desirable as no additional application costs are required. The objectives of this research are to: 1) compare the relative soybean phytotoxicity of eight synthetic auxin herbicides to one another and 2) determine the effects of V5 herbicide, fungicide, and/or slow-release $\mathrm{N}$ co-applications on corn injury and yield. 


\section{LITERATURE CITED}

Al-Khatib, K. and D. Peterson. 1999. Soybean (Glycine max) response to simulated drift from selected sulfonylurea herbicides, dicamba, glyphosate, and glufosinate. Weed Technol. 13:264-270.

Al-Khatib, K., R. Parker, and E. P. Fuerst. 1992. Alfalfa response to simulated herbicide spray drift. Weed Technol. 6:956-960.

Al-Khatib, K., R. Parker, and E. P. Fuerst. 1993. Wine grape response to simulated herbicide drift. Weed Technol. 7:97-102.

Andersen, S. M., S. A. Clay, L. J. Wrage, and D. Matthees. 2004. Soybean foliage residues of dicamba and 2,4-D and correlation to application rates and yield. Agron. J. 96:750-760.

Ashton, F. M. and A. S. Crafts. 1981. Mode of action of herbicides. Wiley-Intersience, New York, NY. 525 pp.

[ASPB] Arkansas State Plant Board. 2012. Class F (2,4-D) Restricted Pesticide List. Arkansas Agriculture Department. 3 p.

Auch, D. E., and W. E. Arnold. 1978. Dicamba use and injury on soybenas (Glycine max) in South Dakota. Weed Sci. 26:471-475.

Barlett, D. W., J. M Clough, J. R. Godwin, A. A. Hall, M. Hamer, and B. ParrDobrzanski. 2002. Review: The strobilurin fungicides. Pest Manag. Sci. 58:649-662.

Behrens, M. R., N. Mutlu, S. Chakraborty, R. Dumitru, W. Z. Jiang, B. J. LaVallee, P. L. Herman, T. E. Clemente, and D. P. Weeks. 2007. Dicamba resistance: Enlarging and preserving biotechnology-based weed management strategies. Science. 316:1185-1188.

Behrens, R. and W. E. Lueschen. 1979. Dicamba volatility. Weed Sci. 27:486-492.

Below, F. E., R. J. Lambert, and R. H. Hageman. 1984. Foliar applications of nutrients on maize. I. yield and $\mathrm{N}$ content of grain and stover. Agron. J. 76:773-777.

Binder, D. L., D. H. Sander, and D. T. Walters. 2000. Maize response to time of nitrogen application as affected by level of nitrogen deficiency. Agron. J. 92:1228-1236.

Boote, K. J., R. N. Gallaher, W. K. Robertson, K. Hinson, and L. C. Hammond. 1978. 
Effect of foliar fertilization on photosynthesis, leaf nutrition, and yield of soybeans. Agron. J. 70:787-791.

Boynton, D. 1954. Nutrition by foliar application. Annu. Rev. Plant Physiol. 5:31-54.

Bradley, C. 2010. Fungicide applicaitons to corn at early growth stages. Retrieved from The Bulletin 3:6: http://bulletin.ipm.illinois.edu/article.php?id=1284.

Bradley, C. 2012. Target diseases when considering foliar fungicides for corn. (University of Illinois Extension) Retrieved from The Bulletin 12:4: http://bulletin.ipm.illinois.edu/article.php?id=1668

Bradley, C. A. and K. A. Ames. 2010. Effect of foliar fungicides on corn with simulated hail damage. Plant Dis. 94:83-86.

Bremner, J. M. 1995. Recent research on problems in the use of urea as a nitrogen fertilizer. Fertil. Res. 42:321-329.

Burnside, O. C., R. W. Bovey, C. L. Elmore, E. L. Knake, C. A. Lembi, J. D. Nalewaja, M. Newton, and P. Szmedra. 1996. Biologic and economic assessment of benefits from use of phenoxy herbicides in the United States. National Agricultural Pesticide Impact Assessment Program.

Cao, M., S. J. Sato, M. Behrens, W. Z. Jiang, T. E. Clemente, and D. P. Weeks. 2011. Genetic engineering of maize (Zea mays) for high-level tolerance to treatment with the herbicide dicamba. J. Agric. Food Chem. 59:5830-5834.

Cranston, H. J., A. J. Kern, J. L. Hackett, E. K. Miller, B. D. Maxwell, and W. E. Dyer. 2001. Dicamba resistance in kochia. Weed Sci. 49:164-170.

Darwin, C. R. 1880. The power of movement in plants. London: John Murray.

Derksen, D. A. 1989. Dicamba, chlorsulfuron, and clopyralid as sprayer contaminants on sunflower, mustard, and lentil, respectively. Weed Sci. 37:616-621.

Donahue, P. J., E. L. Stromberg, and S. L. Meyers. 1991. Inheritance of reaction to gray leaf spot in a diallel cross of 14 maize inbreds. Crop Sci. 41:926-931.

Doran, J. W., W. W. Wilhelm, and J. F. Power. 1984. Crop residue removal and soil productivity with no-till corn, sorghum and soybean. Soil Sci. Soc. Am. J. 48:640-645.

Duke, S. O. and S. B. Powles. 2009. Glyphosate-resistant crops and weeds. Now and in future. Agbioforum. 12:346-357. 
Egan, J. F. and D. A. Mortensen. 2012. Quantifying vapor drift of dicamba herbicides applied to soybeans. Enviorn. Toxicol. Chem. 31:1023-1031.

Everitt, J. D. and J. W. Keeling 2009. Cotton growth and yield response to simulated 2,4-D and dicamba drift. Weed Technol. 23:503-506.

Fageria, N. K., M. P. Barbosa Filho, A. Moreira, and C. M. Guimaraes. 2009. Foliar fertilization of crop plants. J. Plant Nutr. 32:1044-1064. doi:10.1080/01904160902872826.

Farrimond, J. A., M. C. Elliott, and D. W. Clack. 1978. Charge separation as a component of the structural requirements for hormone activity. Nature. 274:401-402.

Finney, K. F., J. W. Meyer, F. W. Smith, and H. C. Fryer. 1957. Effect of foliar spraying of pawnee wheat with urea solutions on yield, protein content, and protein quality. Agron. J. 49:341-347.

Foy, C. D., G. Montenegro, and S. A. Barber. 1953. Foliar feeding of corn with urea nitrogen. Soil Sci. Soc. Am. J. 17:387-390.

Gamble, P. E. and E. R. Emino. 1987. Morphological and anatomical characterization of leaf burn in corn induced from foliar-applied nitrogen. Agron. J. 79:92-96.

Gascho, G. J., J. E. Hook, and G. A. Mitchell. 1984. Sprinkler-applied and side-dressed nitrogen for irrigated corn grown on sand. Agron. J. 76:77-81

Garcia, R. L. and J. J. Hanway. 1976. Foliar fertilization of soybeans during the seedfilling period. Agron. J. 54:653-657.

Gebhardt, M. R., T. C. Daniel, E. E. Schweizer, and R. R. Allmaras. 1985. Conservation tillage. Science. 230:625-630.

Gilbert, F. A. 1946. The status of plant-growth substances and herbicides in 1945. Chem. Rev. 39:199-218.

Green, J. M. and M. D. Owen. 2011. Herbicide-resistant crops: Utilities and limitations for herbicide-resistant weed management. J. Agric. Food Chem. 59:58195829.

Grossmann, K. 2003. Mediation of herbicide effects by hormone interactions. J. Plant Growth Regul. 22:109-122.

Grossmann, K. 2007. Auxin herbicide action: Lifting the veil step by step. Plant Signal. Behav. 2:421-423. 
Grossman, K. 2010. Auxin herbicides: Current status of mechanism and mode of action. Pest Manag. Sci. 66:113-120.

Hanway, J. J. 1962. Corn growth and composition in relation to soil fertility: II. Uptake of N, P, and $\mathrm{K}$ and their distribution in different plant parts during the growing season. Agron. J. 54:217-222.

Harder, H. J., R. E. Carlson, and R. H. Shaw. 1982. Corn grain yield and nutrient response to foliar fertilizer applied during grain fill. Agron. J. 74:106-110.

Heap, I. 2012. International Survey of Herbicide-Resistant Weeds. http://www.weedscience.org. Accessed: September 15, 2012.

Heap, I. and I. N. Morrison. 1992. Resistance to auxin-type herbicides in wild mustard (Sinapis arvensis L.) populations in western Canada. Annu. Meet. Weed Sci. Soc. Amer. Abstra. 32:164.

Hemphill, D. D. and M. L. Montgomery. 1981. Response of vegetable crops to sublethal application of 2,4-D. Weed Sci. 29:632-635.

Herman, P. L., M. Behrens, S. Chakraborty, B. M. Chrastil, J. Barycki, and D. P. Weeks. 2005. A three-component dicamba 0-Demethylase from Pseudomonas maltophilia, strain DI-6. J. Biol. Chem. 280:24759-24767.

Hilty, J. W., C. H. Hadden, and F. T. Garden. 1979. Response of maize hybrids and inbred lines to gray leaf spot disease and the effects on yield in Tennessee. Plant Dis. Rep. 63:515-518.

Holt, J. S. and H. M. LeBaron. 1990. Significance and distribution of herbicide resistance. Weed Technol. 4:141-149.

Jenco, J. H. 1995. Epidemiology of Cercospora zeae-maydis on Zea mays in Iowa. Ph.D. dissertation. Ames, IA: Iowa State University. 69p.

Johnson, V. A., L. R. Fisher, D. L. Jordan, K. E. Edmisten, A. M. Stewart, and A. C. York. 2012. Cotton, peanut, and soybean response to sublethal rates of dicamba, glufosinate, and 2,4-D. Weed Technol. 26:195-206.

Jung, P. E., Jr., L. A. Peterson, and L. E. Schrader. 1972. Response of irrigated corn to time, rate, and source of applied N on sandy soils. Agron. J. 64:668-670.

Kannan, S. and A. Charnel. 1986. Foliar absorption and transport of inorganic nutrients. Crit. Rev. Plant Sci. 4:341-375. 
Kargbo, C. S. 1978. Foliar fertilization of corn during the grain-filling period. Ph.D. dissertation. Ames, IA: Iowa State University.

Kelley, K. B. and D. E. Riechers. 2007. Recent developments in auxin biology and new opportunities for auxinic herbicide research. Pest. Biochem. Physiol. 89:1-11.

Kelley, K. B., L. M. Wax, A. G. Hager, and D. E. Riechers. 2005. Soybean response to plant growth regulator herbicides is affected by other postemergence herbicides. Weed Sci. 53:101-112.

Kirby, C. 1980. The Hormone Weedkillers: A short history of their discovery and development. England: BCPC Publications. 55 pp.

Krausz, R. F., G. Kapusta, and J. L. Matthews. 1993. Soybean (Glycine max) tolerance to 2,4-D ester applied preplant. Weed Technol. 7:906-910.

Lanini, W. T. 2000. Simulated drift of herbicides on grapes, tomatoes, cotton, and sunflower. Proc. Calif. Weed Conf. 52:107-110.

Latterell, F. M. and A. E. Rossi. 1983. Gray leaf spot of corn: A disease on the move. Plant Dis. 67:842-847.

LeBaron, H. M. and J. McFarland. 1990. Herbicide resistance in weeds and crops. Pages 27-55 in M. B. Green, H. M. LeBaron, and W. K. Moberg, ed. Managing Resistance to Agrochemicals: From Fundamental Research to Practical Strategies. Washington D.C.: American Chemical Society.

Lipiec, J. and W. Stepnieski. 1995. Effects of soil compaction and tillage systems on uptake and losses of nutrients. Soil Till. Res. 35:37-52.

Mahmoodi, P., M. Yarnia, R. Amirnia, and M. B. Khorshidi Benam. 2011. Effect of nitrogen foliar application on grain filling rate and period in 3 cultivars of corn (Zea mays L.). Afr. J. Agric. Res. 6:6226-6231.

Marple, M. E., K. Al-Khatib, D. Shoup, D. E. Peterson, and M. Claassen. 2007. Cotton response to simulated drift of seven hormonal-type herbicides. Weed Technol. 21:987-992.

Mithila, J., J. C. Hall, W. G. Johnson, K. B. Kelley, and D. E. Riechers. 2011. Evolution of resistance to auxinic herbicides: Historical perspectives, mechanisms of resistance, and implications for broadleaf weed management in agronomic crops. Weed Sci. 59:445-457.

Munkvold, G. P., C. A. Martinson, J. M. Shriver, and P. M. Dixon. 2011. Probabilities for profitable fungicide use against gray leaf spot in hybrid maize. Phytopathology. 91:477-484. 
Nelson, K. A., P. C. Scharf, W. E. Stevens, and B. A. Burdick. 2010. Rescue nitrogen applications for corn. Soil Sci. Soc. Am. J. 75:143-151.

Noellsch, A. J., P. P. Motavalli, K. A. Nelson, and N. R. Kitchen. 2009. Corn reponse to conventional and slow-release nitrogen fertilizers across a claypan landscape. Agron. J. 103:607-614.

Paniagua, S. M. 2006. Use of slow-release N fertilizer to control nitrogen losses due to spatial and climatic differences in soil moisture conditions and drainage in claypan soils. M.S. thesis. Columbia, MO: University of Missouri. 104 p.

Paul, P. A., L. V. Madden, C. A. Bradley, A. E. Robertson, G. P. Munkvold, G. Shaner, K. A. Wise, D. K. Malvick, T. W. Allen, A. Grybauskas, P. Vincelli, and P. Esker. 2011. Meta-analysis of yield response of hybrid field corn to foliar fungicides in the U.S. corn belt. Phytopathology. 101:1122-1132.

Randall, G. W., T. K. Iragavarapu, and B. R. Bock. 1997. Nitrogen application methods and timing for corn after soybean in a ridge-tillage system. J. Prod. Agric. 10:300-307.

Robertson, A. 2010. Can tank mixing fungicide with post-emergence herbicide increase yield? Retrieved September 26, 2012, from ICM News. Iowa State Univ. Ext.: http://www.extension.iastate.edu/CropNews/2010/0518robertson.htm

Robertson, A., J. Shriver, and D. Mueller. 2012. Evaluation of foliar fungicides applied to corn in 2011. (I. S. Outreach, Editor) Retrieved from Integrated Crop Management News:

http://www.extension.iastate.edu/CropNews/2012/0109robertson.htm

Sarakhsi, H. S., M. Yarnia, and R. Amirniya. 2010. Effect of nitrogen foliar application in different concentration and growth stage of corn (Hybrid 704). Adv. Environ. Biol. 4:291-298.

Scharf, P. C., W. J. Wiebold, and J. A. Lory. 2002. Corn yield response to nitrogen fertilizer timing and deficiency level. Agron. J. 94:435-441.

Sciumbato, A. S., J. M. Chandler, S. A. Senseman, R. W. Bovey, and K. L. Smith. 2004a. Determining exposure to auxin-like herbicides. I. Quantifying injury to cotton and soybean. Weed Technol. 18:1125-1134.

Sciumbato, A. S., J. M. Chandler, S. A. Senseman, R. W. Bovey, and K. L. Smith. 2004b. Determining exposure to auxin-like herbicides. II. Practical application to quantify volatility. Weed Technol. 18:1135-1142. 
Sesay, A. and R. Shibles. 1980. Mineral depletion and leaf senescence in soya bean as influenced by foliar nutrient application during seed filling. Ann. Bot. 45:4755.

Shaner, G., G. Buechley, and R. Johnson. 1999. Effect of fungicides on gray leaf spot. Fung. Nemat. Tests. 54:355-358.

Steckel, L., C. Craig, and A. Thompson. 2005. Cleaning Plant Growth Regulator (PGR) Herbicides Out of Field Sprayers. UT Extension: https://utextension.tennessee.edu/publications/Documents/W071.pdf. September 21, 2012.

Sterling, T. M. and J. Hall. 1997. Mechanism of action of natural auxins and the auxinic herbicides. Pages 111-141 in M. R. Roe, J. D. Burton, and R. J. Kuhr, eds. Herbicide Activity: Toxicology, Biochemistry and Molecular Biology. Washington DC: IOS Press.

Tayler, A. W. and W. F. Spencer. 1990. Volatilization and vapor transport processes. Pages 213-255 in H. H. Cheng, ed. Pesticides in the Soil Environment: Processes, Impacts, and Modeling. Madison, WI: Soil Science Society of America.

Texas Department of Agriculture. 2012. Regulated Herbicide Counties. http://www.texasagriculture.gov/RegulatoryPrograms/Pesticides/Regulate dHerbicides/RegulatedHerbicidesCounties.aspx. September 18, 2012.

Thimann, K. V. 1977. Hormone action in the whole life of plants. Amherst: The University of Massachusetts Press.

[USDA] U.S. Department of Agriculture. 2008. National Agriculture Statistics Service. Farm production expenditures hit record high in 2007, USDA reports. Web page: http://www.nass.usda.gov/Newsroom/2008/08_07_2008.asp

[USDA] U.S. Department of Agriculture. 2009. National Agriculture Statistics Service. Farm production expenditures hit record high in 2009, USDA reports. Web page: http://www.nass.usda.gov/Newsroom/2009/08_06_2009.asp

[USDA] U.S. Department of Agriculture. 2010. Economics, statistics and market information system (ESMIS). Online. USDA, Washington, DC.

[USDA] U.S. Department of Agriculture. 2012. National Agricultural Statistics Service. Farm Production Expenditures 2011 Summary. Web page:http://www.nass.usda.gov/Statistics_by_Subject/Economics_and_Price s/index.asp 
[USDA] U.S. Department of Agriculture. 2012. National Agricultural Statistics Service. Acreage Report. Washington, DC: USDA, National Agricultural Statistics Service (NASS).

Ward, J. M. and D. C. Nowell. 1998. Integrated management practices for the control of maize grey leaf spot. Integr. Pest Manage. Rev. 3:177-188.

Ward, J. M., M. D. Laing, and D. C. Nowell. 1997a. Chemical control of gray leaf spot. Crop Prot. 16:265-271.

Ward, J. M., M. D. Laing, and F. H. Rijkenberg. 1997b. Frequency and timing of fungicide applications for the control of gray leaf spot in maize. Plant Dis. 81:41-48.

Wax, L. M., L. A. Knuth, and F. W. Slife. 1969. Response of soybeans to 2,4-D, dicamba, and picloram. Weed Sci. 17:388-393.

Wegulo, S. N. 1994. Benefits assessment of fungicide usage in seed corn production in Iowa. M.S. thesis. Ames, IA: Iowa State University.

Wegulo, S. N., C. A. Martinson, J. M. Rivera-C, and F. W. Nutter. 1997. Model for economic analysis of fungicide usage in hybrid corn seed production. Plant Dis. 81:415-422.

Wegulo, S. N., J. M. Rivera-C, C. A. Martinson, and F. W. Nutter. 1998. Efficacy of fungicide treatments for control of common rust and northern leaf spot in hybrid corn seed production. Plant Dis. 82:547-554.

Wise, K. and D. Mueller. 2011. Are fungicides no longer just for fungi? An analysis of foliar fungicide use in corn. APSnet Features. doi:10.1094/APSnetFeature2011-0531.

Wolf, T. M., R. Grover, K. Wallace, S. R. Shewchuk, and J. Maybank. 1993. Effect of protective shields on drift and deposition characteristics of field sprayers. Can. J. Plant Sci. 73:1261-1273.

Woodburn, A. T. 2000. Glyphosate: Production, pricing and use worldwide. Pest Manag. Sci. 56:309-312.

Woodward, A. and B. Bartel. 2005. Auxin: regulation, action, and interaction. Ann Bot. 95:707-735.

Wright, T. W., J. M. Lira, T. A. Walsh, D. M. Merlo, N. L. Arnold, J. Ponsamuel, G. Lin, D. R. Pareddy, B. C. Gerwick, C. Cui, D. M. Simpson, T. K. Hoffman, M. A. Peterson, L. B. Braxton, M. Krieger, G. Shan, L. A. Tagliani, C. Blewett, I. Gatti, 
R. A. Herman, D. Fonseca, R. S. Chambers, G. Hanger, and M. Schult. 2010a. Improving and preserving high-performance weed control in herbicide tolerant crops: Development of a new family of herbicide tolerant traits. Abstracts, 239th National Meeting of the American Chemical Society. Washington, DC: American Chemical Society. 202 p.

Wright, T.R., G. Shan, T. A. Walsh, J. M. Lira, C. Cui, P. Song, M. Zhuang, N. L. Arnold, G. Lin, K. Yau, S. M. Russell, R. M. Cicchillo, M. A. Peterson, D. M. Simpson, N. Zhou, J. Ponsamuel, and Z. Zhang. 2010b. Robust crop resistance to broadleaf and grass herbicides provided by aryloxyalkanoate dioxygenase transgenes. PNAS. 107:20240-20245.

[WSSA] Weed Science Society of America. 2011. Resistance and tolerance definitions. http://www.wssa.net/Weeds/Resistance/definitions.htm. Accessed: September 20, 2012. 


\title{
CHAPTER II
}

\section{INFLUENCE OF APPLICATION TIMINGS AND SUB-LETHAL RATES OF SYNTHETIC AUXIN HERBICIDES ON SOYBEAN}

\section{Craig B. Solomon and Kevin W. Bradley}

\begin{abstract}
Synthetic auxin herbicides have long been utilized for the selective control of broadleaf weeds in a variety of crop and non-crop environments. Recently, two agrochemical companies have begun to develop soybean with resistance to 2,4-D and dicamba which may lead to an increase in the application of these herbicides in soybean production areas in the near future. Additionally, little research has been published pertaining to the effects of a newly-discovered synthetic auxin herbicide, aminocyclopyrachlor, on soybean phytotoxicity. Two field trials were conducted in 2011 and 2012 to evaluate the effects of sub-lethal rates of 2,4-D amine, aminocyclopyrachlor, aminopyralid, clopyralid, dicamba, fluroxypyr, picloram, and triclopyr on visible soybean injury, height reduction, yield, and yield components. Each of these herbicides was applied to soybean at the V3 and R2 stages of growth at $0.028,0.28,2.8$, and $28 \mathrm{~g}_{\text {ae }} \mathrm{ha}^{-1}$. Greater height reductions occurred with all herbicides except 2,4-D amine and triclopyr when applied at the V3 compared to the R2 stage of growth. The general order of herbicide-induced height reductions to soybeans when applied at $28 \mathrm{~g}_{\mathrm{ge} \mathrm{ha}} \mathrm{h}^{-1}$, from greatest to least, was aminopyralid > clopyralid $>$ picloram $=$ aminocyclopyrachlor $>$ fluroxypyr $>$ triclopyr $>$ dicamba $>$
\end{abstract}


2,4-D amine. Greater soybean yield loss occurred with all herbicides except 2,4-D amine when applied at the R2 compared to the V3 stage of growth. The only herbicide applied which resulted in no yield loss at either stage was 2,4-D amine. The general order of herbicide-induced yield reductions to soybean when applied at $28 \mathrm{~g}_{\mathrm{ge} \mathrm{ha}}{ }^{-1}$, from greatest to least, was aminopyralid > aminocyclopyrachlor > clopyralid $>$ picloram $>$ fluroxypyr $>$ dicamba $>$ triclopyr $>2,4-D$ amine. The greatest yield reductions resulted from $28 \mathrm{~g}_{\text {ae ha }}{ }^{-1}$ aminopyralid applied to R2 soybean. Results from this research indicate that there are vast differences in the relative phytotoxicity of these synthetic auxin herbicides to soybean, and that the timing of the synthetic auxin herbicide exposure will have a significant impact on the severity of soybean height and/or yield reductions.

\section{INTRODUCTION}

As of $2012,93 \%$ of soybean hectares planted in the United States were genetically-engineered, herbicide-resistant varieties (USDA 2012). Due to the increase in the occurrence of glyphosate-, protoporphyrinogen oxidase- (PPO) and acetolactate synthase/acetohydroxyacid synthase- (ALS/AHAS) resistant weed populations, several new herbicide-resistant crop offerings are expected to be introduced onto the marketplace in the near future. Among these are soybeans that have been genetically modified to withstand applications of either 2,4-D (Wright et al. 2010) or dicamba (Behrens et al. 2007). Although 2,4-D was first introduced in 1945 (Troyer 2001) and dicamba in 1967 (CCME 1999), weeds with resistance to these herbicides have been relatively slow to evolve. To date, only 30 weed species 
in the world have been characterized with resistance to at least one of the members of the synthetic auxin herbicide family (Heap 2013). Specifically, there have been 18 species characterized with resistance to 2,4-D, and 6 with resistance to dicamba (Heap 2013). In these instances, resistance to synthetic auxin herbicides was associated with continuous applications of a single active ingredient over many years, leading to extreme selection pressure in these specific environments (Cranston et al. 2001; Heap and Morrison 1992; Holt and LeBaron 1990).

Common symptoms of off-target movement of synthetic auxin herbicides include leaf cupping, stem and leaf epinasty, cracked and swollen stems, as well as chlorosis and necrosis (Andersen et al. 2004; Al-Khatib and Peterson 1999; Auch and Arnold 1978; Kelley et al. 2005; Sciumbato et al. 2004; Wax et al. 1969). Kelley et al. (2005) described that dicamba applications to soybean resulted in new trifoliate leaves being cupped and crinkled, with higher rates resulting in smaller leaves and reduced overall growth compared to lower rates. Symptoms associated with 2,4-D include leaf and stem epinasty, leaf elongation often known as "strapping", as well as swollen and cracked stems (Kelley et al. 2005; Wax et al. 1969). Clopyralid injury has been described as similar to dicamba, but with more thin, elongated leaves with parallel venation and less leaf cupping (Kelley et al. 2005). Due to the diversity of cropping systems in the United States, it is not uncommon for crops that are tolerant of synthetic auxin herbicides to be grown in close proximity to crops that are more susceptible to these herbicides, and often in rotation with one another (Wax et al. 1969). Thus, off-target movement can become a major concern due to the widespread use of 2,4-D, dicamba, picloram, triclopyr, 
and clopyralid in controlling emerged broadleaf weeds in corn (Zea mays L.), sorghum (Sorghum bicolor L. Moench), small grains, fallow land, turfgrasses, pastures, and rangelands. Injury to susceptible plants from off-target movement of synthetic auxins has been well documented in many crops, including cotton (Gossypium hirsutumL.) (Everitt and Keeling 2009; Johnson et al. 2012; Marple et al. 2007), alfalfa (Medicago sativa L.) (Al-Khatib et al. 1992), common sunflower (Helianthus annuus L.) (Derksen 1989; Lanini 2000), peanut (Arachishypogaea L.) (Johnson et al. 2012), wine grape (Vitisvinifera L.) (Al-Khatib et al. 1993), and many other crops (Derksen 1989; Hemphill and Montgomery 1981; Lanini 2000). As a result, certain states have laws that dictate which synthetic auxin herbicides may be applied, the chemical formulation, and at what time of year (ASPB 2012; Texas Agriculture Code 1984).

Soybean are especially at risk of injury from off-target movement of synthetic auxin herbicides due to their similar geographic vicinity and rotation with monocot crops (Wax et al. 1969). Al-Khatib et al. (1999) evaluated the response of soybean to reduced rates of dicamba and other herbicides when applied at the V2-V3 stage of growth. In their research, $187 \mathrm{~g}$ ae ha-1 of dicamba $(33 \%$ of the labeled use rate in corn) resulted in yield reductions of 92 and $80 \%$, respectively. In the same study, $56.1 \mathrm{~g}$ ae ha-1 of dicamba ( $10 \%$ of the labeled use rate in corn) resulted in yields 45\% lower than the control (Al-Khatib and Peterson 1999). Andersen et al. (2004) found that when $5.6 \mathrm{~g}$ ae ha-1 of dicamba ( $1 \%$ of the labeled use rate in corn) was applied to soybean at the V3 stage of growth, yield reductions of 14 to $34 \%$ occurred. The same study reported that it took applications of $112 \mathrm{~g}$ ae ha-1 $^{-1}$ of 2,4-D 
( $20 \%$ of the labeled use rate in corn), to observe similar yield reductions (Andersen et al. 2004). In a similar study, Kelley et al. (2005) observed that applications of 5.6 g ae ha-1 dicamba to V3 soybean resulted in yield reductions of $6 \%$, while applications of 2,4-D at $180 \mathrm{~g}_{\text {ae }} \mathrm{ha}^{-1}$ resulted in a $25 \%$ yield reduction. Dicamba applications of 0.56 and $5.6 \mathrm{~g}$ ae ha-1 to soybean in the R2 stage of growth resulted in yield reductions of 0 and 7\%, and 2 and $15 \%$ for 56 and $180 \mathrm{~g}$ ae ha-1 of 2,4-D (Kelley et al. 2005). In the same study, clopyralid was applied at 2.1 and $6.6 \mathrm{~g}$ ae ha $^{-1}$ to both V3 and R2 soybeans, resulting in yield reductions of 9 and $15 \%$ for the V3 applications, and 0 and $12 \%$ for the R2 applications (Kelley et al. 2005). With the exception of $5.6 \mathrm{~g}_{\text {ae }} \mathrm{ha}^{-1}$ dicamba, all treatments resulted in lower yields when applied at the V3 compared to the R2 stage of growth (Kelley et al. 2005). This is in contrast to previous research which reported greater injury and yield reductions when dicamba was applied at later soybean growth stages (Auch and Arnold 1978; Slife 1956; Wax et al. 1969). Wax et al. (1969) determined that approximately 16.7 $\mathrm{g}$ ae ha-1 of dicamba applied to soybean at the pre-bloom and bloom growth stages resulted in yield reductions of 11 and 49\%, respectively, with 2,4-D applications at these stages resulting in no yield losses. In the same study, $8.75 \mathrm{~g}^{\mathrm{ae} \mathrm{ha}} \mathrm{h}^{-1}$ of picloram resulted in soybean yield reductions of 18 and $98 \%$ when applied at the pre-bloom and bloom stages, respectively (Wax et al. 1969).

Delayed maturity of soybean following exposure to synthetic auxin herbicides has also been documented in a number of previous experiments (Auch and Arnold 1978; Kelley et al. 2005; Wax et al. 1969). Wax et al. (1969) observed greater maturity delay when dicamba and picloram were applied during the 
reproductive stages, as compared to the earlier vegetative stages. When picloram was applied at $8.75 \mathrm{~g}_{\text {ae }} \mathrm{ha}^{-1}$ to soybean in the pre-bloom and bloom growth stages, soybean maturity was delayed 2 and 27 days, respectively (Wax et al. 1969). Dicamba applied at $16.7 \mathrm{~g}$ ae ha-1 to soybean in the pre-bloom and bloom growth stages resulted in delays in maturity of 4 and 14 days, respectively (Wax et al. 1969). Auch and Arnold (1978) also observed a delay in soybean maturity from foliar applications of dicamba throughout the reproductive growth stages. When comparing early-bloom, mid-bloom, early-pod, and late-pod dicamba applications, most rates and applications resulted in additional delays in maturity as soybean further developed (Auch and Arnold 1978).

The objective of this research was to determine the relative effects of sublethal rates of 2,4-D amine, aminocyclopyrachlor, aminopyralid, clopyralid, dicamba, fluroxypyr, picloram, and triclopyr on visible soybean injury, height reduction, yield, and yield components when applied to plants in the V3 and R2 stages of growth.

\section{MATERIALS AND METHODS}

\section{General Trial Information}

Duplicate field trials were conducted during 2011 and 2012 in Boone County, Missouri at the University of Missouri Bradford Research Center $\left(38^{\circ} 53^{\prime} \mathrm{N}\right.$, $92^{\circ} 12^{\prime} \mathrm{W}$ ). The soil was a Mexico silt loam (fine, smectic, mesic Aeric Vertic Epiaqualfs) with $2.3 \%$ organic matter and $\mathrm{pH}$ of 6.0 in 2011 and a pH of 6.3 and organic matter content of 2.4\% in 2012. On June 6, 2011 and May 22, 2012, Asgrow 3803 glyphosate-resistant soybean were planted into a conventionally-tilled 
seedbed in rows spaced 76-cm apart at a rate of 432,000 seeds ha-1. All treatments were arranged in a randomized complete block (RCB) design with 6 replications. Individual plots were 2 by $8 \mathrm{~m}$ in size. In both years, the entire trial was maintained weed-free with a pre-emergence (PRE) application of sulfentrazone plus cloransulam plus pendimethalin $\left(139+18+780 \mathrm{~g}\right.$ ae ha$\left.^{-1}\right)$ followed by postemergence (POST) applications of glyphosate (1.90 lb ae ha-1). Treatments included the eight synthetic auxin herbicides listed in Table 2.1. Each of these herbicides was applied at the V3 and R2 stages of soybean growth at 0.028, 0.28, 2.8 and $28 \mathrm{~g}$ ae/ai ha $^{-1}$. In 2011, V3 and R2 applications were made on July 1 and August 3, respectively, while in 2012, V3 and R2 applications were made on June 18 and July 13, respectively. All treatments were applied with a $\mathrm{CO}_{2}$-pressurized backpack sprayer equipped with 80025 air induction nozzles delivering $140 \mathrm{~L} \mathrm{ha}^{-1}$ at $117 \mathrm{kPa}$. In an effort to minimize spray drift and/or contamination between plots: 1) drift shields were established on 3 sides of the spray boom during treatment 2) all treatments included a drift reduction agent (InterLock®, $0.2 \% \mathrm{v} \mathrm{v}^{-1}$, Winfield Solutions LLC, P.O. Box 64589, St. Paul, MN 55164-0589) and 3) each herbicide was applied using a specific boom that had never been used before and was designated for that active ingredient only. Monthly rainfall totals and average monthly temperatures for each year are presented in Table 2.2.

\section{Treatment Evaluation and Data Collection}

Visible herbicide injury and soybean height were evaluated at 2 and 4 weeks after treatment (WAT). Visible injury was evaluated on a scale from 0 to $100 \%$, where 0 equals no injury and 100 was equivalent to complete crop death. Soybean 
height was evaluated by measuring 6 random soybean plants per plot (3 from each row) from the soil surface to the top of the central stem. Delayed maturity was measured by recording the day on which $95 \%$ of the soybean pods in each plot reached a mature color and then comparing that with the day when the nontreated control plots reached maturity. Before harvest, a sample of 6 random soybean plants from the center of each plot were collected and used for yield component analysis. Each sample was evaluated by counting the number of seeds per pod and pods per plant to determine an average value for each respective treatment. Soybean were harvested from the center two rows of each plot with a small plot combine and seed yields were adjusted to $13 \%$ moisture content. A 100 count seed sub-sample was collected from each plot to determine seed weight.

\section{Statistical Analysis}

All data were checked for normality to meet basic assumptions prior to statistical analysis. Visible herbicide injury, soybean height, yield component analyses, and soybean yield were subjected to analysis of variance using the PROC MIXED procedure in SAS (SAS 9.2, SAS® Institute Inc.) and tested for appropriate interactions. Year-location combinations were considered an environment sampled at random, as suggested by Carmer et al. (1989) and Blouin et al. (2011). Herbicide, herbicide rate, and application timing were considered fixed effects in the model while environment, replications, sub-samples, and interactions within environment were considered random effects. Analyses were performed on the means and least squares means and detected using Fisher's protected LSD at $\alpha=0.05$. 


\section{RESULTS AND DISCUSSION}

\section{Visible Injury}

At 2 WAT, injury symptoms were dependent on herbicide and rate, regardless of growth stage (Table 2.3). In general, injury intensity increased with increasing herbicide rates. No significant visible injury was noted following any application of 2,4-D amine. Soybean injury was greatest in response to aminopyralid, aminocyclopyrachlor, picloram, clopyralid, and dicamba, and least with triclopyr and 2,4-D amine (Table 2.3).

By 2 WAT, $28 \mathrm{~g}$ ae ha$^{-1}$ aminocyclopyrachlor and picloram applied at the V3 stage of growth resulted in terminal clusters of undeveloped buds, moderate epinasty and chlorosis, with noticeable cupping of leaves. Applications of aminopyralid and clopyralid at the same rate resulted in more necrotic buds and bleached tissues, but less cupping than many of the other synthetic auxin herbicides. Although there were varying degrees of symptomology observed, by 2 WAT of the V3 application timing, $28 \mathrm{~g}$ ae ha-1 aminopyralid, aminocyclopyrachlor, picloram, clopyralid, and fluroxypyr resulted in 56-73\% visible soybean injury, which was the highest observed in these trials (Table 2.3). Dicamba and triclopyr at $28 \mathrm{~g}_{\mathrm{ae} \mathrm{ha}}{ }^{-1}$ resulted in intermediate levels of soybean injury at 44 and 29\%, respectively, with soybean exhibiting less necrotic buds and overall leaf cupping in response to these herbicides. Though leaf cupping is more characteristic of dicamba exposure to soybean, at $28 \mathrm{~g}$ ae ha- ${ }^{-1}$ leaves that developed following herbicide treatment did not expand further than bud clusters; thus, visible leaf cupping was minimal. Similar symptoms have been described previously (Al-Khatib and Peterson 1999; Andersen 
et al. 2004; Auch and Arnold 1978; Kelley et al. 2005; Wax et al. 1969; Weidenhamer et al. 1989). When applied at the V3 stage of growth, $28 \mathrm{~g}$ ae ha-1 2,4-D amine resulted in only $3 \%$ visible soybean injury, which was the lowest level of injury observed in these experiments. There were no leaf or stem epinasty symptoms observed following treatment with triclopyr or 2,4-D amine at any rate.

Applications of aminopyralid, picloram, clopyralid, aminocyclopyrachlor, and dicamba at 2.8 and $0.28 \mathrm{~g}_{\text {ae }} \mathrm{ha}^{-1}$ to soybean in the V3 stage of growth caused noticeable leaf cupping and leaf mottling/puckering, as well as chlorotic, undeveloped bud clusters 2 WAT. Due to fewer necrotic buds and stems, visible injury values were overall lower compared to the $28 \mathrm{~g}$ ae ha-1 rate of these same herbicides. In response to V3 applications of $0.028 \mathrm{~g}_{\text {ae }} \mathrm{ha}^{-1}$ aminopyralid and dicamba, soybean exhibited a moderate degree of leaf cupping and chlorosis of leaf edges, with dicamba displaying more cupped bud clusters than the other synthetic auxin herbicides. No significant visible soybean injury was noted 2 WAT of the V3 applications of $0.028 \mathrm{~g}$ ae ha-1 aminocyclopyrachlor and $0.028,0.28$, and $2.8 \mathrm{~g}$ ae ha1 2,4-D, triclopyr, and fluroxypyr (Table 2.3).

Aminopyralid, clopyralid, picloram, and aminocyclopyrachlor applied at $28 \mathrm{~g}$ ae ha-1 to R2 soybean resulted in the greatest visible injury (30-39\%) 2 WAT (Table 2.3). These treatments resulted in terminal bud death, loss of apical dominance/expansion, and severe stem chlorosis and epinasty. Soybean stems had splits, callouses, and angles of $45-120^{\circ}$. These symptoms predominantly occurred on newer plant tissues, and therefore visible injury ratings were overall much lower than V3 applications. Equivalent applications of dicamba and triclopyr to R2 
soybean resulted in similar bud necrosis/death, but less epinasty and chlorosis. Overall injury was 15 and $18 \%$ in response to $28 \mathrm{~g}_{\text {ae }} \mathrm{ha}^{-1}$ triclopyr and dicamba, respectively (Table 2.3). $\mathrm{R} 2$ applications of $0.028,0.28$, and $2.8 \mathrm{~g}$ ae ha-1 dicamba all resulted in similar levels of leaf cupping/mottling. At the same timing, 0.028, 0.28, and $2.8 \mathrm{~g}_{\text {ae }} \mathrm{ha}^{-1}$ of aminopyralid and clopyralid resulted in terminal leaf cupping/chlorosis and bud abortions, with 0.28 and $2.8 \mathrm{~g}_{\text {ae }} \mathrm{ha}^{-1}$ of aminopyralid displaying unexpanded/undeveloped bud clusters and stem epinasty. Aminocyclopyrachlor at $2.8 \mathrm{~g}$ ae ha-1 exhibited chlorotic terminal leaf cupping and mottling, as well as undeveloped bud clusters similar to aminopyralid. The 0.028 , 0.28 , and $2.8 \mathrm{~g}_{\text {ae }} \mathrm{ha}^{-1}$ rates of picloram applied at R2 resulted in slight cupping of the newest trifoliates. This differential response to the eight synthetic auxin herbicides was not surprising as plants absorb, translocate, and metabolize herbicides at different rates (Devine et al. 1993).

By 4 WAT, all soybean exposed to synthetic auxin herbicides at the V3 growth stage, except for $28 \mathrm{~g}$ ae ha-1 clopyralid, picloram, aminocyclopyrachlor, and 2.8 and $28 \mathrm{~g}$ ae ha- ${ }^{-1}$ of aminopyralid, had recovered significantly from two weeks prior (Table 2.3). Conversely, soybean treated with synthetic auxin herbicides at the R2 stage of growth did not recover as well and in many instances exhibited similar levels of injury as 2 WAT.

\section{Height Reductions}

Previous research has correlated soybean yield loss with reductions in plant height following an application of dicamba (Weidenhamer et al. 1989). In this research, reductions in plant height were generally correlated with, but less severe 
than visible injury estimates. Greater height reductions occurred with all herbicides except for 2,4-D amine and triclopyr when applied at the V3 compared to the R2 stage of growth (Table 2.4). Auch and Arnold (1978) observed that the greatest soybean height reductions from dicamba applications were made at the early-bloom stage, as compared to applications made at vegetative growth stages or from midbloom through late-pod. At 2 WAT, $0.028 \mathrm{~g}$ ae ha-1 ${ }^{-1}$ of aminopyralid, dicamba, and clopyralid applied to V3 soybean were the only herbicides that resulted in soybean height reductions compared to the nontreated control (Table 2.3). All synthetic auxin herbicides except 2,4-D amine applied at $28 \mathrm{~g}$ ae ha-1 ${ }^{-1}$ reduced plant height by at least $20 \%$ in comparison to the nontreated control at both 2 and 4 WAT. When applied at $28 \mathrm{~g}_{\text {ae }} \mathrm{ha}^{-1}$, the general order of herbicide-induced height reductions to soybean, from greatest to least, was aminopyralid $>$ clopyralid $>$ picloram $=$ aminocyclopyrachlor $>$ fluroxypyr $>$ triclopyr $>$ dicamba $>2,4-D$ amine.

\section{Maturity Delay}

The specific herbicide, herbicide rate, and timing of herbicide application had significant effects on the delay in soybean maturity (Table 2.3). In general, applications made to soybean in the R2 stage of growth resulted in greater delays in soybean maturity compared to V3 herbicide applications. Wax et al. (1969) also observed greater maturity delays following dicamba and picloram applications to soybean in the reproductive stages of growth compared to the pre-bloom stages of growth. There were no delays in soybean maturity following any application of 2,4-D amine at either growth stage (Table 2.3). Wax et al. (1969) also reported that dicamba delayed soybean maturity more than 2,4-D. Except for 2,4-D amine, all 
herbicides applied at $28 \mathrm{~g}_{\text {ae }} \mathrm{ha}^{-1}$ to $\mathrm{R} 2$ soybean resulted in maturity delays of at least 18 days, while only the V3 application of the highest rate of aminopyralid caused a maturity delay greater than 8 days (Table 2.4). Picloram, aminopyralid, and aminocyclopyrachlor at $2.8 \mathrm{~g}$ ae ha-1 also resulted in maturity delays of 10 to 16 days when applied to soybean in the R2 stage of growth.

\section{Soybean Yield}

In general, herbicide treatments and rates resulting in less than $10 \%$ visible injury 2 WAT did not reduce yield (Tables 2.3 and 2.4). Except for either application timing of 2,4-D amine and V3 applications of dicamba, all herbicides resulted in greater soybean yield loss with increasing herbicide rates (Table 2.4). Additionally, greater soybean yield loss occurred with applications made to R2 compared to V3 soybean, except for 2,4-D amine, which did not reduce soybean yield compared to the nontreated control at either application timing. This result is consistent with previous research; Slife (1956) and Wax et al. (1969) reported less yield reduction from early compared to later 2,4-D treatments while Robinson et al. (2013) reported soybean yield losses of 5\% with V2 or R2 applications of 2,4-D at rates up to $116 \mathrm{~g}$ ae $\mathrm{ha}^{-1}$.

Soybean yield after R2 applications of dicamba ranged from 2 to $67 \%$ less than the nontreated control, but V3 applications of dicamba did not result in any soybean yield loss. This result is in agreement with previous research, where 9 to $11 \mathrm{~g} \mathrm{ha}^{-1}$ dicamba reduced yields in the flowering stage, compared with pre-bloom applications that required rates of 56 to $70 \mathrm{~g} \mathrm{ha}^{-1}$ to reduce yields (Auch and Arnold 1978; Wax et al. 1969). In relation to the significant visible injury following early- 
season dicamba applications, Behrens and Leuschen (1979) determined yield reductions following dicamba drift injury to soybean at the first trifoliate stage were associated with injury ratings of 60 to 70 or more. Other authors (Auch and Arnold 1978; Slife 1956; Wax et al. 1969) have also noted greater yield reductions following dicamba applications to soybean in the reproductive rather than vegetative stages of growth. Conversely, Kelley et al. (2005) reported equivalent or greater yield reductions from V3 applications of dicamba, 2,4-D and clopyralid compared to R2 applications of these same herbicides. Regardless of growth stage, yields were significantly reduced following $0.28,2.8$, and $28 \mathrm{~g}$ ae ha- ${ }^{-1}$ clopyralid and 2.8 and $28 \mathrm{~g}$ ae ha-1 picloram. Only 2.8 and $28 \mathrm{~g}$ ae ha-1 aminopyralid applied to V3 soybean reduced yield, while all aminopyralid rates applied to $\mathrm{R} 2$ soybean resulted in yields 7 to $97 \%$ less than the nontreated control. Similarly, only $28 \mathrm{~g}_{\text {ae ha}}{ }^{-1}$ aminocyclopyrachlor applied to V3 soybean reduced yield, while the 2.8 and $28 \mathrm{~g}$ ae ha $^{-1}$ rates applied at the R2 stage reduced yield 12 and $90 \%$, respectively. Lastly, only $28 \mathrm{~g}$ ae ha-1 of triclopyr and fluroxypyr applied at either growth stage resulted in yields less than the nontreated control. When applied at $28 \mathrm{~g} \mathrm{ae} \mathrm{ha}^{-1}$, the general order of herbicide-induced yield reductions to soybean from greatest to least was aminopyralid $>$ aminocyclopyrachlor $>$ clopyralid $>$ picloram $>$ fluroxypyr $>$ dicamba $>$ triclopyr $>2,4-$ D.

Interestingly, certain synthetic auxin treatments resulted in yields higher than the nontreated control (Table 2.4). When applied at the R2 stage of growth, $0.028 \mathrm{~g}_{\text {ae ha}}{ }^{-1}$ clopyralid and fluroxypyr resulted in yields 313 and $344 \mathrm{~kg} \mathrm{ha}^{-1}$ greater than the nontreated control. This response may be explained by a 
phenomenon known as herbicide hormesis (Southman and Ehrlich 1943), or the Arndt-Schultz law (Thimann 1956), which states that every toxicant is a stimulant at low levels (Schabenberger et al. 1999). Several other authors have reported stimulatory effects on field crops from low concentrations of 2,4-D and other synthetic auxin herbicides (Miller et al. 1962; Taylor 1946; Wiedman and Appleby 1972).

\section{Soybean Yield Components}

Generally, all synthetic auxin herbicides other than 2,4-D amine reduced soybean seeds per pod in response to increasing herbicide rates. All rates of 2,4-D amine resulted in seeds per pod equivalent to the nontreated control. In general, R2 applications of synthetic auxin herbicides influenced seeds per pod more than V3 applications, but the response varied by herbicide and rate (Table 2.4). Kelley et al. (2005) found that $5.6 \mathrm{~g}_{\text {ae }} \mathrm{ha}^{-1}$ dicamba reduced seeds per pod more when applied to soybean at V7 compared to V3 in one of two years. Dicamba was the only herbicide where all rates applied to R2 soybean resulted in less seeds per pod than the nontreated control (Table 2.4). Following V3 applications, all herbicides except triclopyr and aminopyralid resulted in similar numbers of seeds per pod, regardless of herbicide rate. When compared to the nontreated control, 2.8 and $28 \mathrm{~g}_{\text {ae }} \mathrm{ha}^{-1}$ aminopyralid and $0.028 \mathrm{~g}_{\text {ae }} \mathrm{ha}^{-1}$ triclopyr were the only herbicides applied at the V3 timing that reduced soybean seeds per pod. Overall, seeds per pod were most affected by aminopyralid and least by 2,4-D amine; therefore the number of soybean seeds per pod were strongly correlated with the soybean yield losses observed. 
Following V3 applications, the number of pods per plant was only reduced in response to the highest rate of aminopyralid; all other synthetic auxin herbicides and rates resulted in a similar number of pods per plant as the nontreated control (Table 2.4). Kelley et al. (2005) reported that soybean treated at the V3 and V7 stages with $5.6 \mathrm{~g}_{\text {ae }} \mathrm{ha}^{-1}$ dicamba resulted in a similar number of pods per plant as the nontreated control. In contrast, following R2 applications, the number of pods per plant was highly influenced by herbicide rate. All synthetic auxin herbicides applied at the R2 stage of soybean growth resulted in significant differences in pods per plant in response to rate, with higher rates reducing pods per plant more than lower rates (Table 2.4). The lowest rate of 2,4-D applied to R2 soybean was the only treatment that resulted in more pods per plant than the nontreated control. All rates of aminopyralid, 2.8 and $28 \mathrm{~g}$ ae ha ${ }^{-1}$ dicamba, clopyralid, aminocyclopyrachlor, and fluroxypyr, and $28 \mathrm{~g}$ ae ha- ${ }^{-1}$ picloram and triclopyr applied to R2 soybean reduced pods per plant in comparison to the nontreated control. As with seeds per pod, the differences in pods per plant was greatest with aminopyralid and least with 2,4-D.

Soybean seed weight was variable, with no consistent trend in response to either application timing. When applied at the V3 growth stage, there were no treatments that resulted in soybean seed weight greater than the nontreated control, whereas the same treatments applied to the R2 growth stage resulted in no seed weights less than the nontreated control (Table 2.4). Applications of 2,4-D at either soybean growth stage resulted in similar soybean seed weight as the nontreated control. Robinson et al. (2013) observed similar seed weight as the 
nontreated control with doses $\leq 560 \mathrm{~g}$ ae ha-1 2,4-D. Only $0.028 \mathrm{~g}$ ae ha-1 dicamba, $0.28 \mathrm{~g}_{\text {ae }} \mathrm{ha}^{-1}$ aminocyclopyrachlor, and 0.28 and $2.8 \mathrm{~g}$ ae ha ${ }^{-1}$ clopyralid and aminopyralid applied to V3 soybean resulted in seed weight less than the nontreated control. Wax et al. (1969) reported $>1 \mathrm{~g}$ reductions in seed weight per 100 seeds following pre-bloom applications of 1 to $33 \mathrm{~g}$ ae ha-1 dicamba. Following R2 applications, all rates of dicamba, and several rates of all other synthetic auxin herbicides other than 2,4-D resulted in seed weight greater than the nontreated control (Table 2.5). Weidenhamer et al. (1989) also observed increases in seed weight following later applications of dicamba while earlier dicamba applications reduced seed weight. Wax et al. (1969) also reported greater soybean seed weight from late compared to early-season treatments of dicamba and picloram, noting that the increased seed size did not counteract the reduction in seed number and thus resulted in lower yields. The increase in seed weight was likely due to the reduction in the number of seeds produced.

The results from this research indicate that the risk to soybean from herbicide drift and/or tank contamination is dependent on herbicide, herbicide rate, and maturity of soybean following exposure. Overall, soybean are more likely to recover from misapplications of synthetic auxin herbicides made earlier, rather than later in the growing season. In this research, soybean exposed to synthetic auxin herbicides in early vegetative stages were able to maintain seed and pod set more efficiently than equivalent exposure to these herbicides at reproductive stages. In general, herbicide-induced injury increased with increasing herbicide rate; with aminopyralid, clopyralid, aminocyclopyrachlor, and dicamba resulting in more 
phytotoxicity to soybean than 2,4-D amine, triclopyr, and fluroxypyr. In this study, yield reductions were correlated with seeds per pod and pods per plant more so than seed weight. 


\section{LITERATURE CITED}

Al-Khatib, K. and D. Peterson. 1999. Soybean (Glycine max) response to simulated drift from selected sulfonylurea herbicides, dicamba, glyphosate, and glufosinate. Weed Technol. 13:264-270.

Al-Khatib, K., R. Parker, and E. P. Fuerst. 1992. Alfalfa response to simulated herbicide spray drift. Weed Technol. 6:956-960.

Al-Khatib, K., R. Parker, and E. P. Fuerst. 1993. Wine grape response to simulated herbicide drift. Weed Technol. 7:97-102.

Andersen, S. M., S. A. Clay, L. J. Wrage, and D. Matthees. 2004. Soybean foliage residues of dicamba and 2,4-D and correlation to application rates and yield. Agron. J. 96:750-760.

[ASPB] Arkansas State Plant Board. 2012. Class F (2,4-D) Restricted Pesticide List. Arkansas Agriculture Department.3 p.

Auch, D. E., and W. E. Arnold. 1978. Dicamba use and injury on soybenas (Glycine max) in South Dakota. Weed Sci. 26:471-475.

Behrens, M. R., N. Mutlu, S. Chakraborty, R. Dumitru, W. Z. Jiang, B. J. LaVallee, P. L. Herman, T. E. Clemente, and D. P. Weeks. 2007. Dicamba resistance: Enlarging and preserving biotechnology-based weed management strategies. Science. 316:1185-1188.

Behrens, R. and W. E. Lueschen. 1979. Dicamba volatility. Weed Sci. 27:486-492.

Blouin, D. C., E. P. Webster, and J. A. Bond. 2011. On the analysis of combined experiments. Weed Technol. 25:165-169.

[CCME]Canadian Council of Ministers of the Environment. 1999. Canadian water quality guidelines for the protection of aquatic life:Dicamba. In: Canadian environmental quality guidelines, 1999, Canadian Council of Ministers of the Environment, Winnipeg.

Carmer, S.G., W.E. Nyquist, and W.M. Walker. 1989. Least significant differences for combined analysis of experiments with two or three-factor treatment designs. Agron. J. 81:665-672.

Cranston, H. J., A. J. Kern, J. L. Hackett, E. K. Miller, B. D. Maxwell, and W. E. Dyer. 2001. Dicamba resistance in kochia. Weed Sci. 49:164-170. 
Derksen, D. A. 1989. Dicamba, chlorsulfuron, and clopyralid as sprayer contaminants on sunflower, mustard, and lentil, respectively. Weed Sci. 37:616-621.

Everitt, J. D. and J. W. Keeling 2009. Cotton growth and yield response to simulated 2,4-D and dicamba drift. Weed Technol. 23:503-506.

Heap, I. 2013. International Survey of Herbicide-Resistant Weeds. http://www.weedscience.org. Accessed: April 29, 2013.

Heap, I. and I. N. Morrison. 1992. Resistance to auxin-type herbicides in wild mustard (Sinapis arvensis L.) populations in western Canada. Annu. Meet. Weed Sci. Soc. Amer. Abstra. 32:164.

Hemphill, D. D. and M. L. Montgomery. 1981. Response of vegetable crops to sublethal application of 2,4-D. Weed Sci. 29:632-635.

Holt, J. S. and H. M. LeBaron. 1990. Significance and distribution of herbicide resistance. Weed Technol. 4:141-149.

Johnson, V. A., L. R. Fisher, D. L. Jordan, K. E. Edmisten, A. M. Stewart, and A. C. York. 2012. Cotton, peanut, and soybean response to sublethal rates of dicamba, glufosinate, and 2,4-D. Weed Technol. 26:195-206.

Kelley, K. B., L. M. Wax, A. G. Hager, and D. E. Riechers. 2005. Soybean response to plant growth regulator herbicides is affected by other postemergence herbicides. Weed Sci. 53:101-112.

Lanini, W. T. 2000. Simulated drift of herbicides on grapes, tomatoes, cotton, and sunflower. Proc. Calif. Weed Conf. 52:107-110.

Marple, M. E., K. Al-Khatib, D. Shoup, D. E. Peterson, and M. Claassen. 2007. Cotton response to simulated drift of seven hormonal-type herbicides. Weed Technol. 21:987-992.

Miller, M. D., D. S. Mikkelsen, and R. C. Huffaker. 1962. Effects of stimulatory and inhibitory levels of 2,4-D and iron on growht and yield of field beans. Crop Sci. 2:114-116.

Robinson, A. P., V. M. Davis, D. M. Simpson, and W. G. Johnson. 2013. Response of soybean yield components to 2,4-D. Weed Sci. 61:68-76.

Sciumbato, A. S., J. M. Chandler, S. A. Senseman, R. W. Bovey, and K. L. Smith. 2004. Determining exposure to auxin-like herbicides. I. Quantifying injury to cotton and soybean. Weed Technol. 18:1125-1134. 
Slife, F. W. 1956. The effect of 2,4-D and several other herbicides on weeds and soybeans when applied as post-emergence sprays. Weeds 4:61-68.

Schabenberger, O., B. E. Tharp, J. J. Kells, and D. Penner. 1999. Statistical tests for hormesis and effective dosages in herbicide dose response. Agron. J. 91:713721.

Southman, C. M., and J. Ehrlich. 1943. Effects of extract of western red-cedar heartwood on certain wood-decaying fungi in culture. Phytopathology 33:517-524.

Taylor, D. L. 1946. Observations on the growth of certain plants in nutrient solutions containing synthetic growth-regulating substances. I. Some effects of 2,4-D acid. Bot. Gaz. 107:597-611.

Texas Agriculture Code. 1984. St. Paul, MN: West. Chapter 75.

Thimann, K. V. 1956. Promotion and inhibition: Twin themes of physiology. Am. Nat. 40:145-162.

Troyer, J. R. 2001. In the beginning: the multiple discovery of the first hormone herbicides. Weed Sci. 49:290-297.

[USDA] United States Department of Agriculture. 2012. National Agricultural Statistics Service.Acreage. ISSN:1949-1522.

Wax, L. M., L. A. Knuth, and F. W. Slife. 1969. Response of soybeans to 2,4-D, dicamba, and picloram. Weed Sci. 17:388-393.

Weidenhamer, J. D., G. B. Triplett, Jr., and F. E. Sobotka. 1989. Dicamba injury to soybean. Agron. J. 81:637-643.

Wiedman, S.J., and A.P. Appleby. 1972. Plant growth stimulation by sublethal concentrations of herbicides. Weed Res. 12:65-74.

Wright, T.R., G. Shan, T. A. Walsh, J. M. Lira, C. Cui, P. Song, M. Zhuang, N. L. Arnold, G. Lin, K. Yau, S. M. Russell, R. M. Cicchillo, M. A. Peterson, D. M. Simpson, N. Zhou, J. Ponsamuel, and Z. Zhang. 2010. Robust crop resistance to broadleaf and grass herbicides provided by aryloxyalkanoate dioxygenase transgenes. PNAS. 107:20240-20245. 
Table 2.1 Sources of materials used in the experiment.

\begin{tabular}{|c|c|c|c|}
\hline Common name & Trade name & Formulation & Manufacturer \\
\hline 2,4-D & Weedar 64 & $456 \mathrm{~g} \mathrm{~L}^{-1} \mathrm{EC}$ & $\begin{array}{l}\text { Nufarm, Inc., Burr Ridge, } \\
\text { IL (www.nufarm.com/US }\end{array}$ \\
\hline Dicamba & Clarity & $480 \mathrm{~g} \mathrm{~L}^{-1} \mathrm{EC}$ & $\begin{array}{l}\text { BASF Crop Research } \\
\text { Triangle Park, NC } \\
\text { (www.agro.basf.com) }\end{array}$ \\
\hline Clopyralid & Transline & $360 \mathrm{~g} \mathrm{~L}^{-1} \mathrm{EC}$ & $\begin{array}{l}\text { Dow Agrosciences, } \\
\text { Indianapolis, IN } \\
\text { (www.dowagro.com) }\end{array}$ \\
\hline Picloram & Tordon $22 \mathrm{~K}$ & $240 \mathrm{~g} \mathrm{~L}^{-1} \mathrm{EC}$ & $\begin{array}{l}\text { Dow Agrosciences, } \\
\text { Indianapolis, IN } \\
\text { (www.dowagro.com) }\end{array}$ \\
\hline Triclopyr & $\begin{array}{l}\text { Remedy } \\
\text { Ultra }\end{array}$ & $480 \mathrm{~g} \mathrm{~L}^{-1} \mathrm{EC}$ & $\begin{array}{l}\text { Dow Agrosciences, } \\
\text { Indianapolis, IN } \\
\text { (www.dowagro.com) }\end{array}$ \\
\hline Aminopyralid & Milestone & $240 \mathrm{~g} \mathrm{~L}^{-1} \mathrm{EC}$ & $\begin{array}{l}\text { Dow Agrosciences, } \\
\text { Indianapolis, IN } \\
\text { (www.dowagro.com) }\end{array}$ \\
\hline Aminocyclopyrachlor & MAT28 & $0.50 \mathrm{~g} \mathrm{~g}^{-1} \mathrm{SG}$ & $\begin{array}{l}\text { DuPont Corporation, } \\
\text { Wilmington, DE } \\
\text { (www.dupont.com) }\end{array}$ \\
\hline Fluroxypyr & Starane & $180 \mathrm{~g} \mathrm{~L}^{-1} \mathrm{EC}$ & $\begin{array}{l}\text { Dow Agrosciences, } \\
\text { Indianapolis, IN } \\
\text { (www.dowagro.com) }\end{array}$ \\
\hline
\end{tabular}

anterLock ${ }^{\circledR}$ at $0.208 \% \mathrm{v} / \mathrm{v}$ was added to each herbicide solution 
Table 2.2. Monthly rainfall $(\mathrm{mm})$ and average monthly temperatures $\left({ }^{\circ} \mathrm{C}\right)$ from April through October in 2011 and 2012 in comparison to the 30-yr average in Boone County, Missouri.

\begin{tabular}{|c|c|c|c|c|c|c|}
\hline \multirow[b]{2}{*}{ Month } & \multicolumn{3}{|c|}{ Rainfall } & \multicolumn{3}{|c|}{ Temperature } \\
\hline & 2011 & 2012 & $\begin{array}{c}30-\mathrm{yr} \\
\text { average }^{\mathrm{a}}\end{array}$ & 2011 & 2012 & $\begin{array}{c}30-\mathrm{yr} \\
\text { average }^{\mathrm{a}}\end{array}$ \\
\hline & \multicolumn{3}{|c|}{------------ mm ------------ } & \multicolumn{3}{|c|}{ - } \\
\hline April & 72 & 171 & 121 & 13.6 & 13.9 & 13.6 \\
\hline May & 130 & 25 & 127 & 16.5 & 21.0 & 18.9 \\
\hline June & 77 & 39 & 94 & 24.0 & 24.1 & 23.8 \\
\hline July & 59 & 18 & 101 & 27.6 & 28.5 & 25.7 \\
\hline August & 61 & 5 & 75 & 24.6 & 24.7 & 24.8 \\
\hline September & 46 & 46 & 78 & 17.4 & 18.6 & 20.4 \\
\hline October & 26 & 68 & 99 & 13.8 & 11.7 & 14.0 \\
\hline Total & 471 & 372 & 695 & --- & --- & --- \\
\hline
\end{tabular}


Table 2.3 Soybean injury, rate of maturity, and height in response to eight synthetic auxin herbicides applied at the V3 and R2 stages of soybean growth combined across 2011 and 2012.

\begin{tabular}{|c|c|c|c|c|c|c|c|c|c|c|c|}
\hline \multirow[b]{3}{*}{ Herbicide } & \multirow[b]{3}{*}{ Rate } & \multicolumn{4}{|c|}{ Visible injury $^{a}$} & \multicolumn{4}{|c|}{ Soybean height } & \multicolumn{2}{|c|}{ Maturity } \\
\hline & & \multicolumn{2}{|c|}{2 WAT } & \multicolumn{2}{|c|}{4 WAT } & \multicolumn{2}{|c|}{$2 \mathrm{WAT}$} & \multicolumn{2}{|c|}{ 4 WAT } & \multirow[b]{2}{*}{ V3 } & \multirow[b]{2}{*}{$\mathrm{R} 2$} \\
\hline & & $\mathrm{V}^{\mathrm{c}}$ & $\mathrm{R} 2$ & V3 & $\mathrm{R} 2$ & V3 & $\mathrm{R} 2$ & V3 & $\mathrm{R} 2$ & & \\
\hline \multirow{5}{*}{ 2,4-D amine } & - g ae ha-1 & $----\cdot$ & 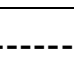 & 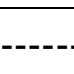 & 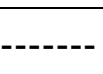 & \multicolumn{4}{|c|}{--- \% of nontreated control ----- } & \multicolumn{2}{|c|}{---\# days --- } \\
\hline & 0.028 & 2 & 0 & 1 & 0 & 96 & 102 & 103 & 103 & 0 & 0 \\
\hline & 0.28 & 1 & 0 & 1 & 1 & 102 & 100 & 101 & 100 & 0 & 0 \\
\hline & 2.8 & 1 & 0 & 0 & 0 & 99 & 101 & 101 & 101 & 0 & 0 \\
\hline & 28 & 3 & 0 & 0 & 0 & 94 & 95 & 99 & 98 & 0 & 0 \\
\hline \multirow[t]{4}{*}{ Aminocyclopyrachlo } & 0.028 & 5 & 3 & 2 & 3 & 103 & 100 & 104 & 101 & 0 & 0 \\
\hline & 0.28 & 11 & 9 & 4 & 8 & 95 & 97 & 99 & 99 & 0 & 0 \\
\hline & 2.8 & 32 & 13 & 11 & 14 & 78 & 85 & 83 & 76 & 4 & 10 \\
\hline & 28 & 70 & 33 & 63 & 29 & 52 & 68 & 47 & 59 & 8 & 23 \\
\hline \multirow[t]{4}{*}{ Aminopyralid } & 0.028 & 31 & 12 & 7 & 9 & 87 & 91 & 92 & 86 & 1 & 1 \\
\hline & 0.28 & 41 & 11 & 14 & 11 & 84 & 91 & 88 & 84 & 1 & 1 \\
\hline & 2.8 & 48 & 14 & 43 & 13 & 74 & 80 & 66 & 71 & 3 & 16 \\
\hline & 28 & 73 & 39 & 65 & 34 & 44 & 59 & 26 & 53 & 21 & 23 \\
\hline \multirow[t]{4}{*}{ Clopyralid } & 0.028 & 7 & 10 & 1 & 7 & 93 & 102 & 97 & 101 & 0 & 0 \\
\hline & 0.28 & 11 & 12 & 2 & 8 & 92 & 96 & 95 & 93 & 0 & 0 \\
\hline & 2.8 & 41 & 14 & 7 & 14 & 83 & 86 & 83 & 80 & 2 & 1 \\
\hline & 28 & 60 & 30 & 68 & 21 & 52 & 56 & 35 & 57 & 8 & 26 \\
\hline \multirow[t]{3}{*}{ Dicamba } & 0.028 & 21 & 15 & 10 & 17 & 89 & 94 & 94 & 89 & 0 & 0 \\
\hline & 0.28 & 28 & 17 & 9 & 16 & 85 & 93 & 90 & 85 & 3 & 0 \\
\hline & 2.8 & 32 & 14 & 9 & 15 & 79 & 86 & 75 & 77 & 3 & 1 \\
\hline
\end{tabular}




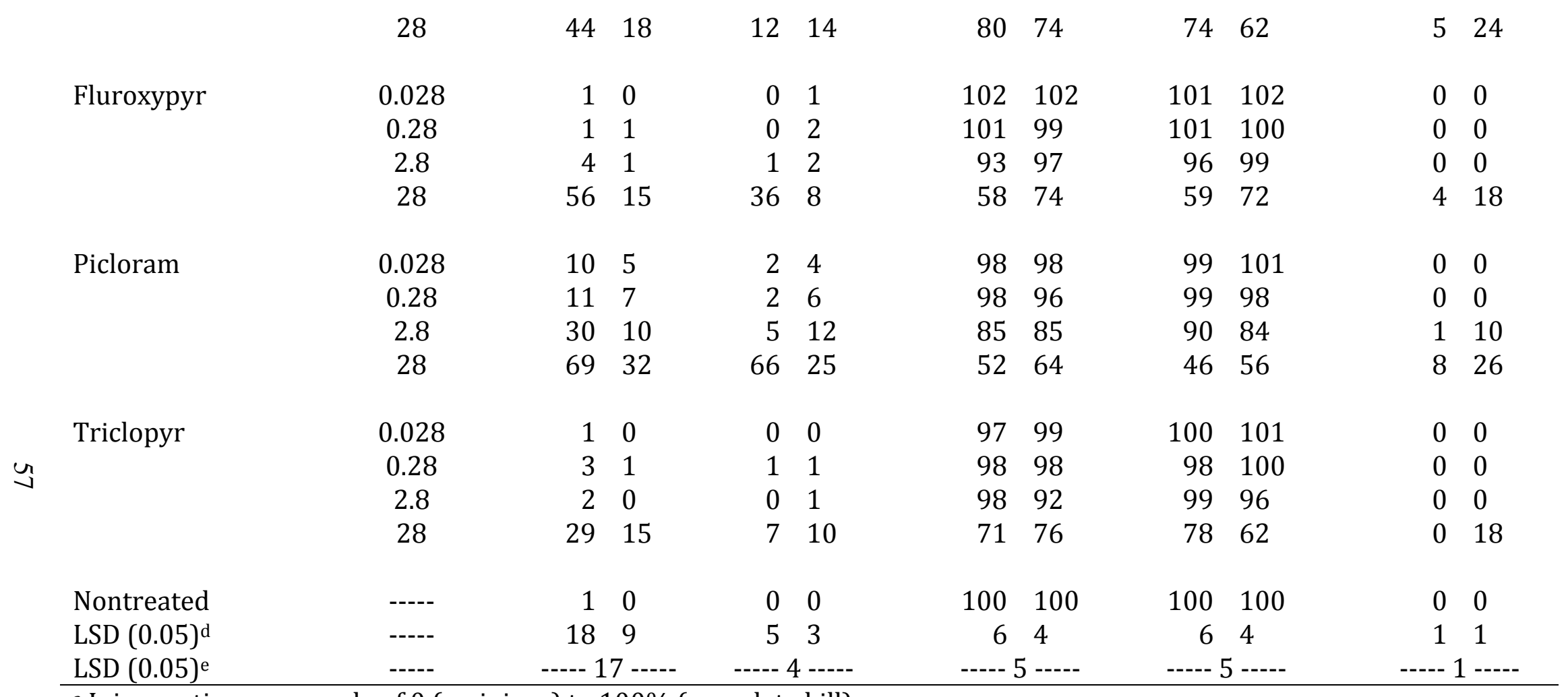

a Injury ratings on a scale of 0 (no injury) to $100 \%$ (complete kill).

b Measured by recording the day when $95 \%$ of the soybean pods in each plot reached maturity compared to the nontreated control.

cAll herbicide applications were applied to V3 and R2 soybean growth stages.

dLSD (0.05) within a column between herbicide treatments applied at the same growth stage.

eLSD (0.05) between growth stages for all herbicide treatments. 
Table 2.4 Soybean yield and yield components in response to eight synthetic auxin herbicides applied at the V3 and R2 stages of soybean growth combined across 2011 and 2012.

\begin{tabular}{|c|c|c|c|c|c|c|c|c|c|}
\hline \multirow[b]{2}{*}{ Herbicide } & \multirow[b]{2}{*}{ Rate } & \multicolumn{2}{|c|}{ Soybean yield } & \multicolumn{2}{|c|}{ Seeds per pod } & \multicolumn{2}{|c|}{ Pods per plant } & \multicolumn{2}{|c|}{ Seed weight } \\
\hline & & $\mathrm{V}^{\mathrm{a}}$ & $\mathrm{R} 2$ & V3 & $\mathrm{R} 2$ & V3 & $\mathrm{R} 2$ & V3 & $\mathrm{R} 2$ \\
\hline \multirow{5}{*}{ 2,4-D amine } & - g ae ha-1 - & ------- kg & ha-1 ------- & 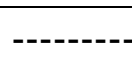 & 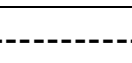 & 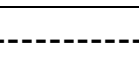 & 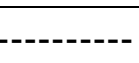 & -- g 100 & $e^{e e d s^{-1}--}$ \\
\hline & 0.028 & 4345 & 4340 & 2.22 & 2.33 & 45 & 55 & 16.77 & 16.62 \\
\hline & 0.28 & 4306 & 4395 & 2.27 & 2.22 & 45 & 53 & 16.68 & 16.83 \\
\hline & 2.8 & 4462 & 4354 & 2.26 & 2.20 & 49 & 48 & 16.63 & 16.66 \\
\hline & 28 & 4306 & 4373 & 2.23 & 2.20 & 51 & 45 & 16.88 & 17.25 \\
\hline \multirow[t]{4}{*}{ Aminocyclopyrachlor } & 0.028 & 4513 & 4466 & 2.28 & 2.24 & 46 & 48 & 16.72 & 17.11 \\
\hline & 0.28 & 4440 & 4594 & 2.20 & 2.18 & 46 & 45 & 16.40 & 17.18 \\
\hline & 2.8 & 4222 & 3823 & 2.27 & 2.02 & 48 & 37 & 16.24 & 19.37 \\
\hline & 28 & 1927 & 435 & 2.23 & 0.19 & 45 & 7 & 16.42 & 17.16 \\
\hline \multirow[t]{4}{*}{ Aminopyralid } & 0.028 & 4141 & 4016 & 2.27 & 2.17 & 45 & 40 & 16.37 & 17.99 \\
\hline & 0.28 & 4086 & 3898 & 2.26 & 2.07 & 49 & 40 & 16.25 & 17.54 \\
\hline & 2.8 & 3329 & 2752 & 2.10 & 1.93 & 44 & 41 & 16.24 & 18.79 \\
\hline & 28 & 423 & 135 & 0.76 & 0.01 & 16 & 1 & 16.61 & 15.87 \\
\hline \multirow[t]{4}{*}{ Clopyralid } & 0.028 & 4369 & 4640 & 2.25 & 2.20 & 44 & 48 & 16.52 & 17.50 \\
\hline & 0.28 & 4015 & 4073 & 2.19 & 2.15 & 47 & 46 & 16.08 & 17.27 \\
\hline & 2.8 & 3944 & 3795 & 2.24 & 2.00 & 48 & 40 & 16.14 & 18.01 \\
\hline & 28 & 1838 & 622 & 2.28 & 0.08 & 49 & 9 & 16.33 & 17.87 \\
\hline \multirow[t]{4}{*}{ Dicamba } & 0.028 & 4147 & 4222 & 2.17 & 2.06 & 45 & 42 & 16.23 & 18.11 \\
\hline & 0.28 & 4260 & 4052 & 2.17 & 2.07 & 50 & 43 & 16.35 & 18.35 \\
\hline & 2.8 & 4178 & 3730 & 2.16 & 2.00 & 45 & 39 & 16.44 & 17.73 \\
\hline & 28 & 4128 & 1427 & 2.20 & 0.64 & 50 & 13 & 16.35 & 18.99 \\
\hline
\end{tabular}




\begin{tabular}{|c|c|c|c|c|c|c|c|c|c|}
\hline \multirow[t]{3}{*}{ Fluroxypyr } & 0.028 & 4463 & 4671 & 2.29 & 2.17 & 50 & 46 & 16.47 & 17.02 \\
\hline & 0.28 & 4447 & 4425 & 2.23 & 2.22 & 45 & 48 & 16.60 & 16.99 \\
\hline & 28 & 3079 & 2306 & 2.30 & 1.07 & 50 & 15 & 16.45 & 18.98 \\
\hline \multirow[t]{3}{*}{ Picloram } & 0.028 & 4464 & 4511 & 2.27 & 2.27 & 47 & 44 & 16.79 & 17.11 \\
\hline & 0.28 & 4401 & 4242 & 2.22 & 2.18 & 45 & 44 & 16.53 & 17.10 \\
\hline & 2.8 & 4088 & 3653 & 2.28 & 2.15 & 44 & 42 & 16.39 & 18.38 \\
\hline \multirow[t]{4}{*}{ Triclopyr } & 0.028 & 4446 & 4464 & 2.13 & 2.20 & 51 & 53 & 16.78 & 16.67 \\
\hline & 0.28 & 4360 & 4550 & 2.25 & 2.23 & 50 & 49 & 16.67 & 17.07 \\
\hline & 2.8 & 4543 & 4513 & 2.35 & 2.33 & 47 & 45 & 16.87 & 17.69 \\
\hline & 28 & 3832 & 2468 & 2.31 & 1.07 & 49 & 11 & 16.45 & 20.41 \\
\hline
\end{tabular}

aAll herbicide applications were applied to V3 and R2 soybean growth stages.

bLSD (0.05) within a column between herbicide treatments applied at the same growth stage.

cLSD (0.05) between growth stages for all herbicide treatments. 
CHAPTER III

\title{
INVESTIGATIONS OF EARLY-SEASON HERBICIDE, FUNGICIDE, AND SLOW- RELEASE NITROGEN CO-APPLICATIONS IN FIELD CORN
}

\section{Craig B. Solomon, Laura Sweets, and Kevin W. Bradley}

\begin{abstract}
Two field trials were conducted in 2011 and 2012 near Columbia, Missouri to determine the effects of herbicide, fungicide, and slow-release $\mathrm{N}$ fertilizer coapplications on corn injury and yield. All trials were arranged in a randomized complete block design with six replications. In the first experiment, the herbicides rimsulfuron plus mesotrione, thiencarbazone-methyl plus tembotrione, $S$ metolachlor plus glyphosate plus mesotrione, glyphosate plus thiencarbazonemethyl plus tembotrione, glyphosate plus atrazine, mesotrione, glyphosate, and glufosinate were applied alone or in combination with the fungicides trifloxystrobin plus prothioconazole, azoxystrobin plus propiconazole, and pyraclostrobin plus metconazole. In the second experiment, the herbicides glyphosate plus thiencarbazone-methyl plus tembotrione, $S$-metolachlor plus glyphosate plus mesotrione, glyphosate, and glufosinate were also applied alone or in combination with these same three fungicides, and all of these herbicide-fungicide combinations were also applied with or without a slow-release nitrogen $(\mathrm{N})$ fertilizer. In both experiments, all treatments were applied at the V5 stage of corn growth. In both
\end{abstract}


years, when averaged across all herbicide treatments, there were no differences in corn yield between any of the fungicide treatments and the weed-free, nontreated control. Also in both years, when averaged across all herbicide and fungicide coapplications, there were no differences in corn yield between treatments that contained a slow-release $\mathrm{N}$ fertilizer compared to those that did not. Disease severity, SPAD meter readings, and stalk strength evaluations were similar for all herbicide and fungicide treatments in comparison to the nontreated control.

Overall, results from these experiments indicate that certain early-season herbicide plus fungicide or herbicide plus fungicide plus slow-release $\mathrm{N}$ fertilizer combinations can cause substantial reductions in corn height, but that V5 coapplications of herbicides with fungicides or slow-release $\mathrm{N}$ fertilizers are not likely to provide increases in corn yield.

\section{INTRODUCTION}

Historically, foliar fungicide applications have proven profitable in seed corn production, where the crop value can be 10 times higher than in grain production (Munkvold et al. 2011; Paul et al. 2011; Shaner et al. 1999; Wegulo et al. 1997; Wegulo et al. 1998). Relatively high chemical and application costs, combined with the uncertainty of disease pressure and the relatively minor effects of diseases on corn yield have generally made fungicide applications in grain production rare. However, due to recent corn prices, the increase in conservation-tillage practices that lead to greater disease potential, and industry claims of substantial yield increases in response to fungicide applications, the use of foliar fungicides on field 
corn has increased dramatically in the past five years (Paul et al. 2011). Fungicide applications have also been promoted for beneficial physiological effects in crops, regardless of disease pressure; further increasing the possibility of profitable fungicide applications (Bradley and Ames 2010). Specifically, the labels of several corn fungicide products include claims of increased stalk strength related to suppression of stalk rot diseases, greater tolerance to hail damage, and more uniform seed size (Anonymous 2008).

Traditionally, applications of fungicides have been made to corn between the tasseling (VT) and silking (R1) stage of growth; however in recent years some pesticide manufacturers have promoted early-season fungicide co-applications with POST herbicide treatments (Robertson 2010). To date, little research has been published on the efficacy or value of early-season (V4-V7) fungicide applications to corn. Though this early application of fungicide may "protect" yield, it is predominately thought of as a supplement to the tasseling application, not a replacement (Robertson 2010). The ability to co-apply fungicides with a POST herbicide application eliminates increased application costs. On the contrary, most of the economically-important foliar diseases which affect corn in this region are either not present at this early stage, or if present, at very low levels (Bradley 2010). Furthermore, unnecessary fungicide applications should be minimized, as many fungicide classes have already been documented as high-risk for the evolution of resistance in fungal species (Barlett et al. 2002).

Results pertaining to the effects of foliar fungicide applications on corn are highly variable and inconsistent across locations. A survey that compared V6 and 
VT-R1 fungicide applications across eight studies from multiple states resulted in an average yield response of $94 \mathrm{~kg} \mathrm{ha}^{-1}$ with V6 applications and $502 \mathrm{~kg} \mathrm{ha}^{-1}$ with VTR1 applications (Bradley 2010). One study in Iowa found little justification for a V6 foliar fungicide application, either alone or in combination with a VT-R1 application (Robertson 2010). In a similar study investigating foliar fungicide applications at V5, R1, and R2 over 6 locations, there were no significant positive yield reponses to any fungicide application, and none of the V5 fungicide applications had an effect on foliar disease severity (Robertson et al. 2012).

Even with economic analyses that provide producers with information about profitable fungicide applications (Munkvold et al. 2011; Paul et al. 2011; Wegulo et al. 1997), decisions on when and where to apply fungicides are still predominantely subjective (Wegulo et al. 1997). Wise and Mueller (2011) compiled information from 39 published trials between 2000 and 2010 that examined the effectiveness of fungicides on hybrid dent corn to assess the likelihood of yield increases following fungicide applications. In 18 of the 39 trials (46\%) they reported significant effects on corn yield. After pooling the 39 trial treatments into a common dataset and selecting only trials that included foliar disease assessments, approximately $80 \%$ of the 472 treatments had a positive yield response from a fungicide application (Wise and Mueller 2011). Since a positive yield response from the additional input does not necessarily relate to a positive economic benefit, the authors determined that $48 \%$ of the 472 treatments resulted in a yield response that met or exceeded their economic break-even value of $377 \mathrm{~kg} \mathrm{ha}^{-1}$ (Wise and Mueller 2011). According to data from Illinois, if at least $15 \%$ of the ear leaf area is affected by disease at the end 
of the season, a foliar fungicide applied between VT and R1 would likely be economically beneficial (Bradley 2012).

Corn is also a nitrogen-demanding crop and nitrogen (N) uptake is often limited in poorly-drained claypan soils, or in fields where losses from denitrification, volatilization, and/or leaching are more likely to occur (Lipiec and Stepniewski 1995). Noellsch et al. (2009) found that the targeted use of slowrelease $\mathrm{N}$ products across claypan landscapes could increase grain yields and profitability compared to conventional $\mathrm{N}$ fertilizers. The timing of these slowrelease N products could coincide with early-season applications of POST herbicides in corn, again exploiting the use of inputs with no additional application costs (Paniagua 2006).

Foliar-applied $\mathrm{N}$ has been shown to increase nutrient content in the grain of wheat (Finney et al. 1957), soybean (Boote et al. 1978), and corn (Harder et al. 1982; Jung et al. 1972; Kargbo 1978). However, even with increases in nutrient concentrations, yields have been shown to be equivalent or less than the nontreated control (Below et al. 1984; Harder et al. 1982; Kargbo 1978). Though Garcia and Hanway (1976) reported significant soybean yield increases in response to applications of balanced N, P, K, and S solutions during grain fill, Boote et al. (1978) observed that foliar applicatioins of N, P, K, and S to soybeans resulted in less yield than the nontreated control. Sesay and Shibles (1980) also reported no yield response from foliar applications of N, P, and K in two soybean cultivars. In regards to corn, a variety of reports have shown significant yield increases from POST N 
applications at V5 through tasseling (Binder et al. 2000; Jung et al. 1972; Nelson et al. 2010; Randall et al. 1997; Scharf et al. 2002).

One of the main issues associated with foliar $\mathrm{N}$ applications is the resulting leaf injury caused by any sizeable quantity of $\mathrm{N}$ applied (Foy et al. 1953). Nelson et al. (2010) evaluated rescue $\mathrm{N}$ applications to corn from $\mathrm{N}$ sources either broadcasted or applied between-row (BR). Their results indicated that when ammonium nitrate or urea-ammonium nitrate was broadcast on corn, leaf injury resulted in reduced yield compared with a BR application (Nelson et al. 2010). When comparing broadcast and BR applications, minimal injury and equivalent yields were observed from urea or urea plus $N$-(n-butyl) thiophosphoric triamide (Nelson et al. 2010). Many authors have hypothesized that losses in leaf area due to the burning and necrotic spots from the fertilizer salts is at least partly responsible for the lack of positive yield responses (Below et al. 1984; Boote et al. 1978; Foy et al. 1953; Harder et al. 1982; Nelson et al. 2010). Gamble and Emino (1987) examined the morphological characteristics associated with corn leaf burn from urea, and concluded the visual damage appeared to be related to water loss since the epidermal and mesophyll cells became desiccated. Bremner (1995) explained that the leaf burn following urea applications was a result of an accumulation of toxic ammounts of urea in the leaves, rather than formation of toxic amounts of $\mathrm{NH}_{3}$ through hydrolysis of urea by leaf urease.

Limited research has been conducted to determine the effects of POST herbicides and slow-release $\mathrm{N}$ fertilizers on corn leaf injury and yield. The objective 
of this research was to determine the effects of V5 herbicide, fungicide, and/or slowrelease $\mathrm{N}$ co-applications on corn injury and yield.

\section{MATERIALS AND METHODS}

\section{General Trial Information}

Two separate field trials were conducted during 2011 and 2012 in Boone County, Missouri at the University of Missouri Bradford Research Center $\left(38^{\circ} 53^{\prime} \mathrm{N}\right.$, $92^{\circ} 12^{\prime} \mathrm{W}$ ). Experiment 1 investigated herbicide and fungicide co-applications applied to corn at the V5 stage of growth while Experiment 2 investigated herbicide, fungicide, and slow-release $\mathrm{N}$ co-applications applied at the V5 stage of corn growth. The soil type for all experiments was a Mexico silt loam (fine, smectic, mesic Aeric Vertic Epiaqualfs) with 2.3\% organic matter and pH of 6.0 in 2011 and a pH of 6.3 and organic matter content of 2.4\% in 2012. On May 5, 2011 and April 4, 2012, Pioneer 1395 glyphosate-resistant corn was planted for both experiments into a conventionally-tilled seedbed in rows spaced $76-\mathrm{cm}$ apart, at a rate of 80,000 seeds ha $^{-1}$. All treatments for both experiments were arranged in a randomized complete block design with 6 replications. Individual plots were 2 by $9 \mathrm{~m}$ in size. In both years, all experiments received a blanket application of atrazine plus $S$-metolachlor $\left(1.3+1.0 \mathrm{~kg} \mathrm{ha}^{-1}\right)$ prior to planting. For both experiments, V5 applications were made on June 8, 2011 and May 16, 2012. In each experiment, all treatments were applied using a self-propelled small-plot sprayer equipped with TeeJet@ 8002XR

flat-fan nozzles (Spraying Systems Co., P.O. Box 7900, Wheaton, IL 60187) delivering $140 \mathrm{~L} \mathrm{ha}^{-1}$ at $117 \mathrm{kPa}$. All treatments were applied with adjuvants according to 
manufacturers and label recommendations. A complete list of the agrochemicals evaluated in each experiment is provided in Table 3.1. A nontreated control was included in each experiment for comparison and all non-herbicide treated plots were kept weed-free by hand-hoeing. Monthly rainfall totals and average monthly temperatures for each year are presented in Table 3.2.

\section{Treatment Evaluation and Data Collection}

Visual herbicide injury and corn height were evaluated 1 and 2 weeks after treatment (WAT). Visual injury was evaluated on a scale from 0 to $100 \%$, with 0 equivalent to the corn vigor and leaf color observed in the nontreated control plots and 100 equivalent to complete crop death. Corn height was evaluated by measuring 5 random corn plants per plot from the soil surface to the tip of the uppermost vertically extended leaf. In both years and both trials, late-season leaf chlorophyll readings were taken on 6 random corn plants in each plot. For each corn plant, readings were taken on the ear leaf, corn leaf above the ear leaf, and the corn leaf below the ear leaf. At the same time, visible disease severity was rated by evaluating the same leaves as the chlorophyll readings and estimating the percent of leaf area infected. When the trials were assessed for presence of fungal foliar diseases, gray leaf spot (GLS) was the only foliar disease present at levels sufficient to warrant rating. Therefore, GLS was the only disease evaluated in both years. However, in 2012 GLS severity was less than $0.1 \%$ across both trials and therefore 2012 evaluations were not included in the analysis. Prior to harvest, stalk strength measurements were taken by evaluating 10 random corn plants per plot for their ability to withstand breakage following a horizontal "arms-length" extension. In 
both years, corn was harvested from the center two rows of each plot with a small plot combine and seed yields adjusted to $15.5 \%$ moisture content.

\section{Statistical Analysis}

All data were checked for normality to meet basic assumptions prior to statistical analysis. Visual herbicide injury, corn height, and corn yield were subjected to analysis of variance using the PROC MIXED procedure in SAS (SAS 9.2, SAS ${ }^{\circledR}$ Institute Inc.) and tested for appropriate interactions. Year-location combinations were considered an environment sampled at random, as suggested by Carmer et al. (1989) and Blouin et al. (2011), and because there was homogeneity of error variances. Herbicide, fungicide, and fertilizer treatments were considered fixed effects in the model while environment, replications, sub-samples, and interactions within environment were considered random effects. Analyses for the data were performed on the means and least squares means and detected using Fisher's protected LSD at $\alpha=0.05$.

\section{RESULTS}

\section{Experiment 1}

The effects of herbicide and herbicide-fungicide co-applications were significant on corn injury 1 WAT, while only the herbicide factor was significant for corn injury 2 WAT (Table 3.3). Visible corn injury following V5 herbicide and fungicide co-applications was only higher than the nontreated control with treatments containing thiencarbazone plus tembotrione and thiencarbazone plus tembotrione plus glyphosate. At 1 WAT, corn injury was 4 to $8 \%$ from applications 
of thiencarbazone plus tembotrione and thiencarbazone plus tembotrione plus glyphosate, and 0 to $2 \%$ from all other tank-mix combinations (Table 3.4). Corn injury generally appeared within the first week after application and was characterized as chlorosis of the whorl and stunting via internode stacking. Similar trends were observed 2 WAT, but with lesser visible injury than a week prior (Table 3.4). When compared to applications of the herbicides alone, no fungicide coapplication increased visible corn injury except in the case of the addition of the fungicides trifloxystrobin plus prothioconazole to thiencarbazone plus tembotrione and thiencarbazone plus tembotrione plus glyphosate, and the addition of azoxystrobin plus propiconazole to thiencarbazone plus tembotrione.

In comparison to the weed-free nontreated control, corn height was reduced with all fungicide combinations that were applied with rimsulfuron plus mesotrione, thiencarbazone plus tembotrione, and thiencarbazone plus tembotrione plus glyphosate 1 WAT (Table 3.4). The effect of herbicide, fungicide, and herbicidefungicide co-applications were all significant on corn height at both 1 and 2 WAT (Table 3.3). One WAT, corn height was reduced by 10 to $19 \%$ with treatments containing thiencarbazone plus tembotrione and thiencarbazone plus tembotrione plus glyphosate and by 4 to $11 \%$ with treatments containing rimsulfuron plus mesotrione. All other tank-mix combinations resulted in less than $6 \%$ height reduction in comparison to the weed-free nontreated control. By 2 WAT, very few herbicide and fungicide combinations resulted in corn heights different than the weed-free nontreated control, with no height reductions greater than $4 \%$. 
Across all herbicide and fungicide co-applications, there was no treatment that resulted in corn yields different than the weed-free nontreated control. When considering all the factors, there was no effect that had a significant impact on seed yield (Table 3.3). Additionally, chlorophyll content and stalk strength assessments were not significant for any factor (Table 3.3). In 2011, when averaged across all herbicide treatments, gray leaf spot severity was lower with treatments that contained a fungicide $(0.32-0.41 \%)$ compared to those that did not $(0.53 \%)$. In 2012, disease pressure was less than $0.1 \%$ throughout the trial.

\section{Experiment 2}

Regardless of the addition of a slow-release $\mathrm{N}$ fertilizer, treatments containing thiencarbazone plus tembotrione plus glyphosate resulted in significant visible corn injury in comparison to all the other combinations evaluated. The effects of herbicide, fungicide, and herbicide-fungicide co-applications were significant on corn injury 1 WAT, while only the herbicide factor was significant for corn injury 2 WAT (Table 3.5). At 1 WAT, treatments containing thiencarbazone plus tembotrione plus glyphosate resulted in 3 to $6 \%$ visible corn injury, while all other combinations evaluated exhibited less than $2 \%$ injury (Table 3.6). By 2 WAT, visible corn injury was less than $4 \%$ in response to all treatments evaluated. As in Experiment 1, corn injury generally appeared within the first week after applications and was characterized as chlorosis of the whorl and stunting via internode stacking. The addition of the slow-release $\mathrm{N}$ fertilizer did not have an effect on visible corn injury. 
Similar to the visual injury estimates, corn height reductions were only observed following applications that included the herbicide treatment thiencarbazone plus tembotrione plus glyphosate. The effects of herbicide and fungicide were significant for corn height 1 WAT, while only the fungicide factor had a significant effect on corn height 2 WAT (Table 3.5). In comparison to the weedfree nontreated control 1 WAT, fungicide and slow-release $\mathrm{N}$ fertilizer combinations containing thiencarbazone plus tembotrione plus glyphosate resulted in height reductions of 10 to $15 \%$, while all other herbicide, fungicide, and fertilizer combinations resulted in corn heights 0 to $5 \%$ less than the weed-free nontreated control (Table 3.6). By 2 WAT, no greater than a 4\% height reduction was observed following any application when compared to the weed-free nontreated control (Table 3.6). The addition of a slow-release $\mathrm{N}$ fertilizer did not have an effect on corn height following any tank-mix combination.

Following all applications applied to corn in the V5 stage of growth, the only treatment that resulted in corn yield less than the weed-free nontreated control was the application of a slow-release $\mathrm{N}$ fertilizer without an herbicide or fungicide (Table 3.6). This is likely due to the fact that these non-herbicide treated plots were kept weed-free by hand-hoeing, and likely experienced either weed competition or stalk damage from the hoeing which negatively influenced yield. Chlorophyll content and stalk strength assessments were not significant for any factor (Table 3.6). In 2011, when averaged across all herbicide treatments, gray leaf spot severity was lower with treatments that contained a fungicide (0.93-1.08\%) compared to 
those that did not (1.36\%). In 2012, disease pressure was less than $0.1 \%$ throughout the trial.

\section{DISCUSSION}

Although significant visual corn injury and height reductions can occur with treatments containing thiencarbazone plus tembotrione and rimsulfuron plus mesotrione, based on the results of this research, corn yields are not likely to be reduced with these herbicide treatments. In low disease environments, even if disease severity is slightly reduced, V5 herbicide and fungicide co-applications in corn are not likely to increase corn grain yields in comparison to herbicide treatments alone. Also, the addition of a slow-release $\mathrm{N}$ fertilizer to these herbicide and fungicide co-applications is not likely to increase corn yield in comparison to the nontreated control.

Current recommendations for fungicide applications include considerations of hybrid susceptibility, agronomic practices, field history, and a disease threshold (Munkvold 1998), though these factors are relatively qualitative. Unfortunately, there is not a simple formula for deciding whether or not a fungicide application will be profitable. By definition, the profitability of a fungicide application is linked to the magnitude of the yield difference between the treated and nontreated corn, which is affected by overall yield potential, hybrid resistance and tolerance, and disease level (Munkvold et al. 2011). When disease pressure is low, the results from this research provide little justification for an early season (V5-V6) foliar fungicide application. Additionally, previous research does not support an early-season foliar 
fungicide application, either alone or in combination with a VT-R1 application (Robertson 2010; Robertson et al. 2012).

In regards to herbicide and fungicide combinations, fungal resistance has been documented and can develop rapidly (Bartlett et al. 2002; Heaney et al. 2000). Fungal cross-resistance, meaning that if a fungus is resistant to one fungicide in the strobilurin group it is likely resistant to all strobilurin fungicides, is another consideration of excess fungicide applications (Heaney et al. 2000). Due to these issues, along with profitability, producers should attempt to use fungicide applications only when conditions favor disease development and subsequent yield loss. 


\section{LITERATURE CITED}

Anonymous. 2008. Headline Fungicide Supplemental Label NVA 2008-04-088-0327. BASF Corporation. BASF Corp., Research Triangle Park, NC.

Barlett, D. W., J. M Clough, J. R. Godwin, A. A. Hall, M. Hamer, and B. Parr-Dobrzanski. 2002. Review: The strobilurin fungicides. Pest Manag. Sci. 58:649-662.

Below, F. E., R. J. Lambert, and R. H. Hageman. 1984. Foliar applications of nutrients on maize. I. Yield and N content of grain and stover. Agron. J. 76:773-777.

Binder, D. L., D. H. Sander, and D. T. Walters. 2000. Maize response to time of nitrogen application as affected by level of nitrogen deficiency. Agron. J. 92:1228-1236.

Boote, K. J., R. N. Gallaher, W. K. Robertson, K. Hinson, and L. C. Hammond. 1978. Effect of foliar fertilization on photosynthesis, leaf nutrition, and yield of soybeans. Agron. J. 70:787-791.

Blouin, D. C., E. P. Webster, and J. A. Bond. 2011. On the analysis of combined experiments. Weed Technol. 25:165-169.

Bradley, C. 2010. Fungicide applicaitons to corn at early growth stages. Retrieved September 29, 2012 from The bulletin 3:6.http://bulletin.ipm.illinois.edu/article.php?id=1284.

Bradley, C. 2012. Target diseases when considering foliar fungicides for corn. Retrieved February 2, 2013 from The bulletin 12:4. http://bulletin.ipm.illinois.edu/article.php?id=1668.

Bradley, C. A. and K. A. Ames. 2010. Effect of foliar fungicides on corn with simulated hail damage. Plant Dis. 94:83-86.

Bremner, J. M. 1995. Recent research on problems in the use of urea as a nitrogen fertilizer. Fertil. Res. 42:321-329.

Carmer, S.G., W.E. Nyquist, and W.M. Walker. 1989. Least significant differences for combined analysis of experiments with two or three-factor treatment designs. Agron. J. 81:665-672.

Devine, M. D., S. O. Duke, and C. Fedtke. 1993. Physiology of Herbicide Action. Englewood Cliffs, NJ: PTR Prentice-Hall. Pp. 29-52.

Finney, K. F., J. W. Meyer, F. W. Smith, and H. C. Fryer. 1957. Effect of foliar spraying of pawnee wheat with urea solutions on yield, protein content, and protein quality. Agron. J. 49:341-347. 
Foy, C. D., G. Montenegro, and S. A. Barber. 1953. Foliar feeding of corn with urea nitrogen. Soil Sci. Soc. Am. J. 17:387-390.

Gamble, P. E. and E. R. Emino. 1987. Morphological and anatomical characterization of leaf burn in corn induced from foliar-applied nitrogen. Agron. J. 79:92-96.

Garcia, R. L. and J. J. Hanway. 1976. Foliar fertilization of soybeans during the seedfilling period. Agron. J. 54:653-657.

Harder, H. J., R. E. Carlson, and R. H. Shaw. 1982. Corn grain yield and nutrient response to foliar fertilizer applied during grain fill. Agron. J. 74:106-110.

Heaney, S.P., A.A. Hall, S.A. Davis, and G. Olaya. 2000. Resistance to fungicides in the QoI-STAR cross-resistance group: current perspectives. BCPC Conference: Pests and diseases. 2:755-762.

Jung, P. E., Jr., L. A. Peterson, and L. E. Schrader. 1972. Response of irrigated corn to time, rate, and source of applied N on sandy soils. Agron. J. 64:668-670.

Kargbo, C. S. 1978. Foliar fertilization of corn during the grain-filling period. Ph.D. dissertation.Iowa State University.

Lipiec, J. and W. Stepnieski. 1995. Effects of soil compaction and tillage systems on uptake and losses of nutrients. Soil Till. Res. 35:37-52.

Munkvold, G. P. 1998. Controlling gray leaf spot in field corn. Integr. Crop Mngmnt. 480:129-130.

Munkvold, G. P., C. A. Martinson, J. M. Shriver, and P. M. Dixon. 2011. Probabilities for profitable fungicide use against gray leaf spot in hybrid maize.

Phytopathology. 91:477-484.

Nelson, K. A., P. C. Scharf, W. E. Stevens, and B. A. Burdick. 2010. Rescue nitrogen applications for corn. Soil Sci. Soc. Am. J. 75:143-151.

Noellsch, A. J., P. P. Motavalli, K. A. Nelson, and N. R. Kitchen. 2009. Corn reponse to conventional and slow-release nitrogen fertilizers across a claypan landscape. Agron. J. 103:607-614.

Paniagua, S. M. 2006. Use of slow-release N fertilizer to control nitrogen losses due to spatial and climatic differences in soil moisture conditions and drainage in claypan soils. M.S. thesis. University of Missouri.

Paul, P. A., L. V. Madden, C. A. Bradley, A. E. Robertson, G. P. Munkvold, G. Shaner, K. A. Wise, D. K. Malvick, T. W. Allen, A. Grybauskas, P. Vincelli, and P. Esker. 
2011. Meta-analysis of yield response of hybrid field corn to foliar fungicides in the U.S. corn belt. Phytopathology 101:1122-1132.

Randall, G. W., T. K. Iragavarapu, and B. R. Bock. 1997. Nitrogen application methods and timing for corn after soybean in a ridge-tillage system. J. Prod. Agric. 10:300-307.

Robertson, A. 2010. Can tank mixing fungicide with post-emergence herbicide increase yield? Retrieved September 26, 2012 from ICM News. http://www.extension.iastate.edu/CropNews/2010/0518robertson.htm

Robertson, A., J. Shriver, and D. Mueller. 2012. Evaluation of foliar fungicides applied to corn in 2011. (I. S. Outreach, Editor) Retrieved August 3, 2012 from ICM News. http://www.extension.iastate.edu/CropNews/2012/0109robertson.htm

Scharf, P. C., W. J. Wiebold, and J. A. Lory. 2002. Corn yield response to nitrogen fertilizer timing and deficiency level. Agron. J. 94:435-441.

Sesay, A. and R. Shibles. 1980. Mineral depletion and leaf senescence in soya bean as influenced by foliar nutrient application during seed filling. Ann. Bot. 45:4755.

Shaner, G., G. Buechley, and R. Johnson. 1999. Effect of fungicides on gray leaf spot. Fung. Nemat. Tests. 54:355-358.

Ward, J. M. and D. C. Nowell. 1998. Integrated management practices for the control of maize grey leaf spot. Integr. Pest Manage. Rev. 3:177-188.

Wegulo, S. N. 1994. Benefits assessment of fungicide usage in seed corn production in Iowa. M.S. thesis.Iowa State University.

Wegulo, S. N., C. A. Martinson, J. M. Rivera-C, and F. W. Nutter. 1997. Model for economic analysis of fungicide usage in hybrid corn seed production. Plant Dis. 81:415-422.

Wegulo, S. N., J. M. Rivera-C, C. A. Martinson, and F. W. Nutter. 1998. Efficacy of fungicide treatments for control of common rust and northern leaf spot in hybrid corn seed production. Plant Dis. 82:547-554.

Wise, K. and D. Mueller. 2011. Are fungicides no longer just for fungi? An analysis of foliar fungicide use in corn. APSnet Features. doi:10.1094/APSnetFeature2011-0531. 
Table 3.1. Monthly rainfall ( $\mathrm{mm}$ ) and average monthly temperatures $\left({ }^{\circ} \mathrm{C}\right)$ from April through October in 2011 and 2012 in comparison to the 30 -yr average in Boone County, Missouri.

\begin{tabular}{|c|c|c|c|c|c|c|}
\hline \multirow[b]{2}{*}{ Month } & \multicolumn{3}{|c|}{ Rainfall } & \multicolumn{3}{|c|}{ Temperature } \\
\hline & 2011 & 2012 & $\begin{array}{c}30-\mathrm{yr} \\
\text { average }^{\mathrm{a}}\end{array}$ & 2011 & 2012 & $\begin{array}{c}30-y r \\
\text { average }^{a}\end{array}$ \\
\hline & \multicolumn{3}{|c|}{--------- mm ---------- } & \multicolumn{3}{|c|}{----- on ------ } \\
\hline April & 72 & 171 & 121 & 13.6 & 13.9 & 13.6 \\
\hline May & 130 & 25 & 127 & 16.5 & 21.0 & 18.9 \\
\hline June & 77 & 39 & 94 & 24.0 & 24.1 & 23.8 \\
\hline July & 59 & 18 & 101 & 27.6 & 28.5 & 25.7 \\
\hline August & 61 & 5 & 75 & 24.6 & 24.7 & 24.8 \\
\hline September & 46 & 46 & 78 & 17.4 & 18.6 & 20.4 \\
\hline October & 26 & 68 & 99 & 13.8 & 11.7 & 14.0 \\
\hline Total & 471 & 372 & 695 & --- & --- & --- \\
\hline
\end{tabular}


Table 3.2 Sources of material for agrochemicals.

\begin{tabular}{|c|c|c|c|c|}
\hline Common name & $\begin{array}{l}\text { Trade } \\
\text { name }\end{array}$ & Formulation & Rate & Manufacturer \\
\hline \multirow[b]{2}{*}{$\begin{array}{l}\text { Rimsulfuron + } \\
\text { mesotrione }\end{array}$} & \multicolumn{4}{|c|}{-kg ae ha-1- } \\
\hline & Realm Q & $\begin{array}{l}0.075 \mathrm{~g} \mathrm{~g}^{-1} \\
0.313 \mathrm{~g} \mathrm{~g}^{-1}\end{array}$ & $\begin{array}{l}0.20 \\
0.90\end{array}$ & $\begin{array}{l}\text { DuPont Corporation, } \\
\text { Wilmington, DE } \\
\text { (www.dupont.com) }\end{array}$ \\
\hline Mesotrione & Callisto & $480 \mathrm{~g} \mathrm{~L}^{-1}$ & 0.11 & $\begin{array}{l}\text { Syngenta Corp., Greensboro, } \\
\text { NC } \\
\text { (www.syngentacropprotectio } \\
\text { n.com) }\end{array}$ \\
\hline$S$-metolachlor + & Halex GT & $250 \mathrm{~g} \mathrm{~L}^{-1}$ & 1.20 & Syngenta Corp., Greensboro, \\
\hline Glyphosate + & & $250 \mathrm{~g} \mathrm{~L}^{-1}$ & 1.20 & \\
\hline Mesotrione & & $25.0 \mathrm{~g} \mathrm{~L}^{-1}$ & 0.12 & $\begin{array}{l}\text { (www.syngentacropprotectio } \\
\text { n.com) }\end{array}$ \\
\hline $\begin{array}{l}\text { Thiencarbazone- } \\
\text { methyl + } \\
\text { Tembotrione }\end{array}$ & Capreno & $\begin{array}{l}68 \mathrm{~g} \mathrm{~L}^{-1} \\
345 \mathrm{~g} \mathrm{~L}^{-1}\end{array}$ & $\begin{array}{l}0.15 \\
0.80\end{array}$ & $\begin{array}{l}\text { Bayer CropScience, Research } \\
\text { Triangle Park, NC } \\
\text { (www.cropscience.bayer.com) }\end{array}$ \\
\hline Glyphosate & $\begin{array}{l}\text { Roundup } \\
\text { Powermax }\end{array}$ & $540 \mathrm{~g} \mathrm{~L}^{-1}$ & 0.86 & $\begin{array}{l}\text { Monsanto Company, St. Louis, } \\
\text { MO (www.monsanto.com) }\end{array}$ \\
\hline Atrazine & Aatrex 4L & $480 \mathrm{~g} \mathrm{~L}^{-1}$ & 1.12 & $\begin{array}{l}\text { Syngenta Corp., Greensboro, } \\
\text { NC } \\
\text { (www.syngentacropprotectio } \\
\text { n.com) }\end{array}$ \\
\hline Glufosinate & Ignite 280 & $280 \mathrm{~g} \mathrm{~L}^{-1}$ & 0.45 & $\begin{array}{l}\text { Bayer CropScience, Research } \\
\text { Triangle Park, NC } \\
\text { (www.cropscience.bayer.com) }\end{array}$ \\
\hline Trifloxystrobin + & Stratego & $375 \mathrm{~g} \mathrm{~L}^{-1}$ & 0.11 & Bayer CropScience, Research \\
\hline Prothioconazole & YLD & $126 \mathrm{~g} \mathrm{~L}^{-1}$ & 0.04 & $\begin{array}{l}\text { Triangle Park, NC } \\
\text { (www.cropscience.bayer.com) }\end{array}$ \\
\hline Azoxystrobin + & Quilt Xcel & $141 \mathrm{~g} \mathrm{~L}^{-1}$ & 0.11 & Syngenta Corp., Greensboro, \\
\hline Propiconazole & & $122 \mathrm{~g} \mathrm{~L}^{-1}$ & 0.09 & $\begin{array}{l}\text { NC } \\
\text { (www.syngentacropprotectio } \\
\text { n.com) }\end{array}$ \\
\hline Pyraclostrobin + & Headline & $146 \mathrm{~g} \mathrm{~L}^{-1}$ & 0.11 & BASF Crop Research Triangle \\
\hline Metconazole & AMP & $55 \mathrm{~g} \mathrm{~L}^{-1}$ & 0.04 & $\begin{array}{l}\text { Park, NC } \\
\text { (www.agro.basf.com) }\end{array}$ \\
\hline Urea $\mathrm{N}+$ & Nitamin & $12 \mathrm{~g} \mathrm{~g}^{-1}$ & 2.24 & Koch Fertilizer LLC, Wichita, \\
\hline $\begin{array}{l}\text { Triazone- } \\
\text { Methylene Urea }\end{array}$ & $30 \mathrm{~L}$ & $18 \mathrm{~g} \mathrm{~g}^{-1}$ & 3.36 & KS (www.kochfertilizer.com) \\
\hline
\end{tabular}


Table 3.3 Analysis of variance of corn injury, corn height, and seed yield following V5 herbicide and fungicide co-applications. Studies were conducted near Columbia, MO during 2011 and 2012.

\begin{tabular}{|c|c|c|c|}
\hline Evaluation & Herbicide & Fungicide & $\begin{array}{l}\text { Herbicide } \mathrm{x} \\
\text { Fungicide }\end{array}$ \\
\hline & ------------ & --- P value & ---------------. \\
\hline Seed yield & 0.6498 & 0.2475 & 0.7517 \\
\hline \multicolumn{4}{|l|}{ Corn injury } \\
\hline 1 WATa & $<0.0001$ & 0.2240 & 0.0033 \\
\hline 2 WAT & $<0.0001$ & 0.5469 & 0.2372 \\
\hline \multicolumn{4}{|l|}{ Corn height } \\
\hline $1 \mathrm{WAT}$ & $<0.0001$ & $<0.0001$ & $<0.0001$ \\
\hline $2 \mathrm{WAT}$ & $<0.0001$ & 0.0273 & 0.0007 \\
\hline \multicolumn{4}{|l|}{ Chlorophyll content } \\
\hline Leaf above ear leaf & 0.5915 & 0.4998 & 0.1523 \\
\hline Ear leaf & 0.9714 & 0.6690 & 0.3936 \\
\hline Leaf below ear leaf & 0.8840 & 0.6192 & 0.8081 \\
\hline Stalk strength & 0.8135 & 0.9658 & 0.9745 \\
\hline Gray leaf spot severityb & 0.5051 & 0.0007 & 0.4550 \\
\hline
\end{tabular}

aAbbreviation: WAT, weeks after treatment

bData from 2011 only. Disease severity was less than $0.1 \%$ throughout the trial in 2012, and thus not included in analysis. 
Table 3.4 Influence of V5 herbicide and fungicide co-applications on injury and yield in field corn.

\begin{tabular}{|c|c|c|c|c|c|c|}
\hline \multirow[b]{2}{*}{ Herbicide } & \multirow[b]{2}{*}{ Fungicide } & \multicolumn{2}{|c|}{ Visible Injury } & \multicolumn{2}{|c|}{ Height } & \multirow[b]{2}{*}{ Yield } \\
\hline & & $1 \mathrm{WAT}^{\mathrm{a}}$ & 2 WAT & $1 \mathrm{WAT}$ & $2 \mathrm{WAT}$ & \\
\hline & & (------- & |0------- & $---\%$ of $C$ & ontrol--- & --kg ha-1-- \\
\hline \multirow[t]{4}{*}{ Glufosinate } & None & 1 & 1 & 97 & 99 & 4258 \\
\hline & Trifloxy+ Proth & 1 & 1 & 99 & 99 & 4144 \\
\hline & Azoxy+Prop & 2 & 1 & 99 & 98 & 4176 \\
\hline & Pyracl+Metcon & 1 & 1 & 97 & 98 & 4091 \\
\hline \multirow[t]{4}{*}{ Glyphosate } & None & 0 & 1 & 100 & 99 & 4428 \\
\hline & Trifloxy+ Proth & 1 & 0 & 97 & 98 & 4227 \\
\hline & Azoxy+Prop & 1 & 0 & 100 & 100 & 4330 \\
\hline & Pyracl+Metcon & 1 & 1 & 96 & 98 & 4166 \\
\hline \multirow{4}{*}{$\begin{array}{l}\text { Glyphosate + } \\
\text { Atrazine }\end{array}$} & None & 1 & 1 & 100 & 99 & 4415 \\
\hline & Trifloxy+ Proth & 1 & 1 & 94 & 98 & 4240 \\
\hline & Azoxy+Prop & 2 & 1 & 97 & 97 & 4514 \\
\hline & Pyracl+Metcon & 0 & 0 & 98 & 99 & 4270 \\
\hline \multirow[t]{4}{*}{ Mesotrione } & None & 1 & 0 & 97 & 100 & 4198 \\
\hline & Trifloxy+Proth & 1 & 2 & 96 & 99 & 4297 \\
\hline & Azoxy+Prop & 1 & 1 & 97 & 99 & 4183 \\
\hline & Pyracl+Metcon & 0 & 1 & 98 & 100 & 4391 \\
\hline \multirow{4}{*}{$\begin{array}{l}\text { Rimsulfuron + } \\
\text { Mesotrione }\end{array}$} & None & 2 & 2 & 95 & 100 & 4105 \\
\hline & Trifloxy+ Proth & 2 & 1 & 89 & 100 & 4513 \\
\hline & Azoxy+Prop & 2 & 1 & 92 & 100 & 4520 \\
\hline & Pyracl+Metcon & 2 & 2 & 96 & 99 & 4527 \\
\hline
\end{tabular}




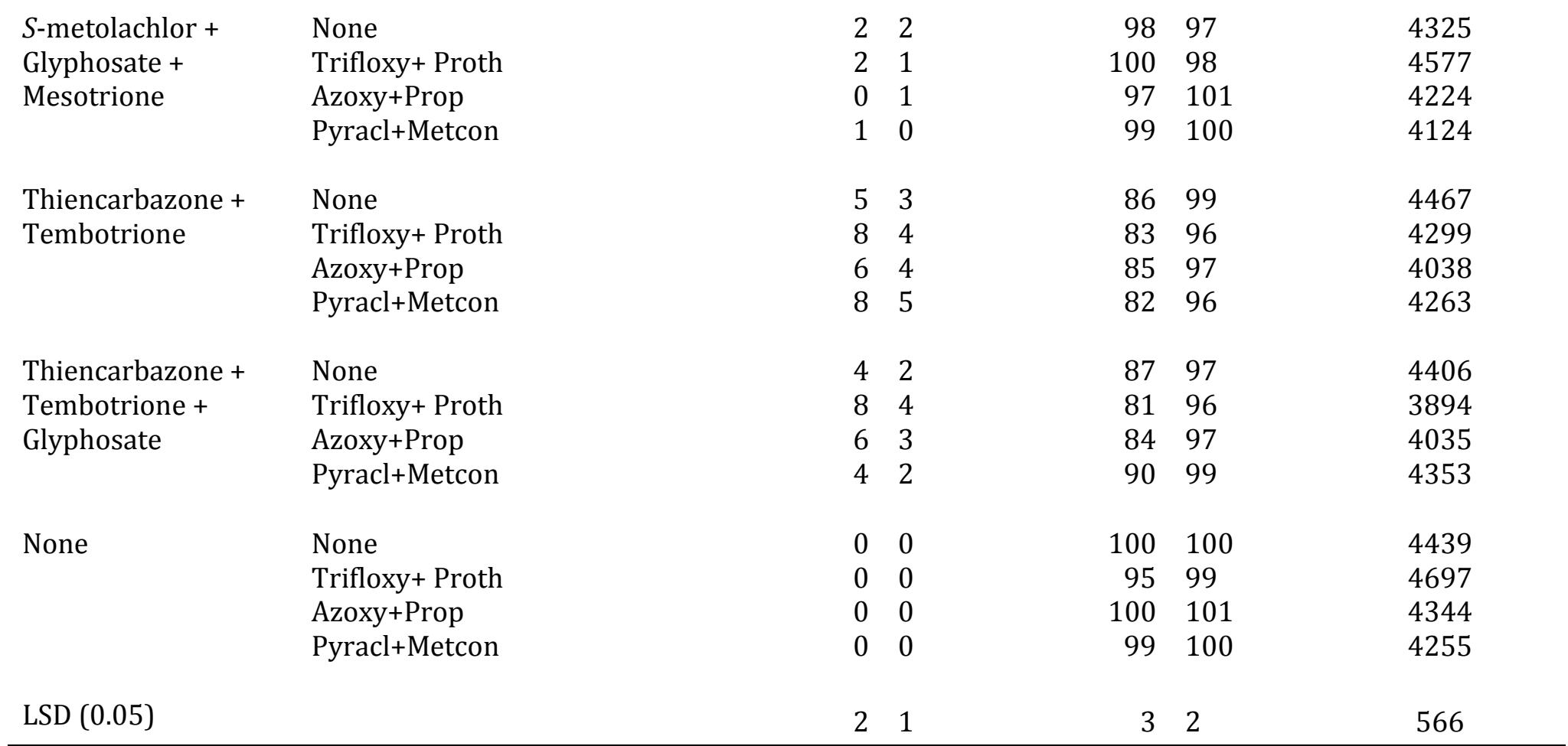

aAbbreviation:WAT, weeks after treatment; Trifloxy+Proth, trifloxystrobin+prothioconazole; Azoxy+Prop, azoxystrobin+propiconazole; Pyracl+Metcon, pyraclostrobin+metconazole. 
Table 3.5. Analysis of variance for corn injury, corn height, and seed yield following V5 herbicide, fungicide, and N fertilizer co-applications. Studies were conducted near Columbia, MO during 2011 and 2012.

\begin{tabular}{|c|c|c|c|c|c|c|c|}
\hline Evaluation & Herb $^{a}$ & Fung & Fert & $\begin{array}{l}\text { Herb x } \\
\text { Fung }\end{array}$ & $\begin{array}{c}\text { Herb x } \\
\text { Fert }\end{array}$ & $\begin{array}{c}\text { Fung } \mathrm{x} \\
\text { Fert }\end{array}$ & $\begin{array}{c}\text { Herb } x \\
\text { Fung } x \\
\text { Fert } \\
\end{array}$ \\
\hline $\begin{array}{l}\text { Seed yield } \\
\text { Corn injury }\end{array}$ & 0.1214 & 0.6929 & 0.8659 & $\begin{array}{l}\text { P value } \\
0.2445\end{array}$ & 0.8744 & 0.4917 & 0.4171 \\
\hline $1 \mathrm{WAT}$ & $<0.0001$ & 0.0316 & 0.3438 & 0.0162 & 0.6818 & 0.3507 & 0.7842 \\
\hline 2 WAT & $<0.0001$ & 0.6643 & 0.7974 & 0.8444 & 0.5043 & 0.9121 & 0.8866 \\
\hline Corn height & & & & & & & \\
\hline $1 \mathrm{WAT}$ & $<0.0001$ & 0.0025 & 0.1514 & 0.0819 & 0.9356 & 0.0697 & 0.1586 \\
\hline $\begin{array}{l}2 \text { WAT } \\
\text { Chlorophyll } \\
\text { content }\end{array}$ & $<0.0001$ & 0.2405 & 0.0110 & 0.0161 & 0.0143 & 0.0023 & 0.0005 \\
\hline $\begin{array}{l}\text { Leaf above ear } \\
\text { leaf }\end{array}$ & 0.7511 & 0.4243 & 0.3285 & 0.1790 & 0.5959 & 0.3009 & 0.5359 \\
\hline Ear leaf & 0.6433 & 0.2134 & 0.9253 & 0.2134 & 0.6027 & 0.1400 & 0.7162 \\
\hline $\begin{array}{l}\text { Leaf below ear } \\
\text { leaf }\end{array}$ & 0.7815 & 0.3574 & 0.8306 & 0.6356 & 0.1569 & 0.7366 & 0.7851 \\
\hline Stalk strength & 0.2711 & 0.3689 & 0.3467 & 0.4889 & 0.1340 & 0.8160 & 0.9536 \\
\hline GLS b & 0.2442 & 0.0030 & 0.1389 & 0.4193 & 0.4879 & 0.3648 & 0.7713 \\
\hline
\end{tabular}

aAbbreviation: Herb, herbicide; Fung, fungicide; Fert, fertilizer; WAT, weeks after treatment

bData from 2011 only. Disease severity was less than $0.1 \%$ throughout the trial in 2012 , and thus not included in analysis. 
Table 3.6 Influence of V5 herbicide, fungicide, and fertilizer co-applications on injury and yield in field corn.

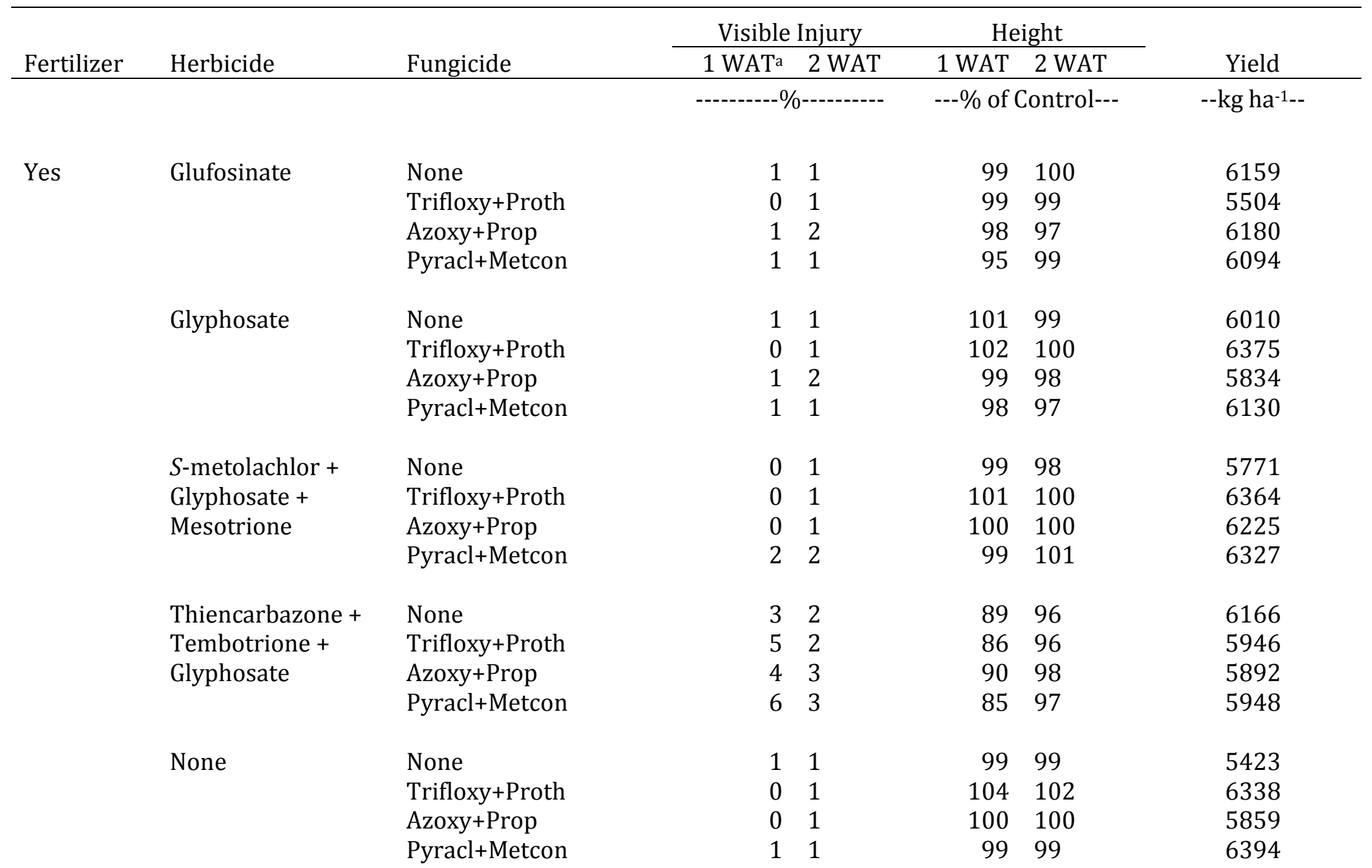




\begin{tabular}{|c|c|c|c|c|c|c|c|}
\hline \multirow[t]{4}{*}{ No } & \multirow[t]{4}{*}{ Glufosinate } & None & 0 & 2 & 97 & 100 & 5979 \\
\hline & & Trifloxy+Proth & 1 & 2 & 99 & 98 & 5897 \\
\hline & & Azoxy+Prop & 1 & 2 & 98 & 100 & 5589 \\
\hline & & Pyracl+Metcon & 1 & 2 & 97 & 97 & 5961 \\
\hline & \multirow[t]{4}{*}{ Glyphosate } & None & 0 & 1 & 100 & 100 & 6069 \\
\hline & & Trifloxy+Proth & 1 & 1 & 98 & 100 & 6291 \\
\hline & & Azoxy+Prop & 0 & 1 & 100 & 102 & 6234 \\
\hline & & Pyracl+Metcon & 0 & 1 & 100 & 100 & 5731 \\
\hline & \multirow{4}{*}{$\begin{array}{l}S \text {-metolachlor + } \\
\text { Glyphosate + } \\
\text { Mesotrione }\end{array}$} & None & 0 & 1 & 102 & 101 & 6119 \\
\hline & & Trifloxy+Proth & 0 & 1 & 99 & 100 & 6188 \\
\hline & & Azoxy+Prop & 0 & 0 & 98 & 100 & 5933 \\
\hline & & Pyracl+Metcon & 1 & 1 & 99 & 99 & 6456 \\
\hline \multirow[t]{8}{*}{$\stackrel{\infty}{+}$} & \multirow{4}{*}{$\begin{array}{l}\text { Thiencarbazone + } \\
\text { Tembotrione }+ \\
\text { Glyphosate }\end{array}$} & None & 4 & 3 & 88 & 99 & 6176 \\
\hline & & Trifloxy+Proth & 5 & 2 & 87 & 97 & 6145 \\
\hline & & Azoxy+Prop & 5 & 3 & 86 & 98 & 5672 \\
\hline & & Pyracl+Metcon & 5 & 1 & 87 & 97 & 5825 \\
\hline & \multirow[t]{4}{*}{ None } & None & 0 & 0 & 100 & 100 & 6149 \\
\hline & & Trifloxy+Proth & 0 & 0 & 102 & 100 & 6055 \\
\hline & & Azoxy+Prop & 1 & 1 & 98 & 100 & 6381 \\
\hline & & Pyracl+Metcon & 0 & 1 & 99 & 101 & 6156 \\
\hline LSD & & & 1 & 1 & 3 & 2 & 709 \\
\hline
\end{tabular}

aAbbreviation: WAT, weeks after treatment; Trifloxy+Proth, trifloxystrobin+prothioconazole; Azoxy+Prop, azoxystrobin+propiconazole; Pyracl+Metcon, pyraclostrobin+metconazole. 